\title{
Rudra Kavi and the Mughal Elite: A Codicological
}

\section{Reappraisal}

\section{PRANAV PRAKASH}

\begin{abstract}
This essay offers a codicological analysis of three manuscripts—Bühler 70a (Ms. 7089), Bühler 7ob (Ms. 7304) and Bühler 7oc (Ms. 7303) -of the British Library, which contain some panegyrics composed by Rudra Kavi (fl. 1570s-1650s). Based on a critical appraisal of handwriting, colophons, watermark and other textual attributes, this essay shows that the three Bühler manuscripts constitute a composite volume of an incomplete anthology of Rudra's panegyric poems. Furthermore, it corroborates how deftly and faithfully all three manuscripts were copied by just one scribe sometime between 1840 and 1880. His exemplar, however, was a draft edition of a few unfinished panegyrics that the poet had been composing simultaneously in praise of some prominent members of the Mughal elite. These findings about the material production and reception history of the Bühler manuscripts illuminate both the craft of an adept scribe and the creative imaginings of a court-poet. For want of a rigorous codicological analysis, previous scholarship has held the scribe responsible for the 'fragmentary' and 'corrupt' condition of these manuscripts and applauded the Brahmin poet for his literary prowess. This essay distances itself from such unwarranted privileging of a court-poet and marginalisation of a skilled scribe. Instead, it seeks codicological and textual evidence in determining the roles played by poets and scribes in the production of literary manuscripts. This essay ultimately reaffirms the value of codicological reflections in the fields of South Asian historiography and literary studies.
\end{abstract}

Keywords: Bühler manuscripts; codicology of Sanskrit manuscripts; South Asian manuscriptoogy; critical textual editions; Sanskrit scribes; Sanskrit court poetry; Campū kāvya; panegyric poems; Sanskrit in Mughal empire; Mughal historiography

\section{Introduction}

Three manuscripts of the British Library-Bühler 70a (Ms. 7089), 70b (Ms. 7304) and 70c (Ms. 7303) — contain some panegyrics composed by Rudra Kavi (fl. I570s-I650s). ${ }^{1}$ Two

\footnotetext{
${ }^{1}$ Not much is known about the poet's life and background. For previous scholarship on his life and works, see: Audrey Truschke, Culture of Encounters: Sanskrit at the Mughal Court (New York, 20I6), pp. 65, 8 I-88, I97-I98, 
successive rulers of the Bāglāṇa kingdom, Pratāp Śāh and his son Nārāyan Śāh, employed Rudra as their court-poet. ${ }^{2}$ Bāglāna was a minor kingdom located on the trade routes running from Surat to Daulatabad, Burhanpur and Golconda. ${ }^{3}$ Its strategic location made it vulnerable to the imperial ambitions of Sultanate and Mughal rulers, who sought to establish their strongholds in this region. ${ }^{4}$ Aware of their modest resources and manpower, the rulers of Bāglāna had followed a policy of appeasing their neighbouring imperial powers by means of tributes and diplomatic co-operation. Mughal elites and emissaries, therefore, frequented the Bāglāna court. On such occasions, court-poets were often called upon to honour and praise their royal visitors. At the behest of his patrons, Rudra began composing Dānaśähacarita (DC), Nabābakhānakhānacarita (NKC), Jahānḡ̄racarita (JC) and Kìrtisamullāsa (KS), alternatively titled Khurammacarita (KC), in honour of Dāniyāl Mīrzā (I 572-I605), 'Abd al-Rahīm Khān Khānān (I556-I626), Jahāngīr (I 569-I627; r.I605-I627) and Shāh Jahān (I592-I666; r.I628-I658) respectively. These panegyrics belonged to the campu genre in which poets freely mix poetic verses with prose passages. ${ }^{5}$ His earliest work is the semi-historical poem Rạstrauḍavamśamahākāvya (RVM), which he completed in I 596. This poem narrates the history of the Bāgula dynasty from the time of its founder, Rāṣtrauḍha, a king of Kannauj, until the rule of Nārāyaṇa Shāh, a king of Mayūragiri (Mulher), in Maharashtra. Unlike RVM, a

200; Audrey Truschke, 'Regional Perceptions: Writing to the Mughal Court in Sanskrit,' in Cosmopolitismes en Asie du Sud: Sources, itinéraires, langues (XVI - XVIII siècle), edited by Corinne Lefêvre, Ines G. Županov and Jorge Flores (Paris, 20I5), pp. 25I-273; Audrey Truschke, 'Cosmopolitan Encounters: Sanskrit and Persian at the Mughal Court,' (PhD dissertation, Columbia University, 20I2), pp. 39, 72-8I, 330-333; Pratāp Kumār Mishra, Śrimad-rudrakavi-viracitam Navābakhānakhānācaritam (Vārānasīi, 2007); J. L. de Bruyne, Rudrakavi's Great Poem of the Dynasty of Rāstraudha: Cantos 1-13 and 18-20 (Leiden, 1968), pp. ix-xii; Jatindra Bimal Chaudhuri, Works of Rudra of the Court of Pratapsimha (Calcutta, I959); Jatindra Bimal Chaudhuri, Muslim Patronage to Sanskritic Learning (Calcutta, I954-59); V. W. Karambelkar, 'Nabābakhānakhānānacaritam,' The Indian Historical Quarterly, (ed.) Narendranath Law, xxviii (I952), pp. 240-248; V. W. Karambelkar, 'Nabābakhānakhānānacaritam,' Nāgarīpracāriṇ̄ Patrikā, Keśava Smṛti An̉ka (I952), pp. 296-297; Har Datt Sharma, 'The Poet Rudra and His Works,' in Woolner Commemoration Volume, (ed.) Mohammad Shafi (Lahore, I940), pp. 24I-244; C. D. Dalal, 'Introduction,' Râshtraudhavańsakâvya of Rudrakavi, (ed.) Embar Krishnamacharya (Baroda, I9I7), pp. i-xxi.

${ }^{2}$ See: RVM 2.27. Rulers of the Bāgula dynasty claimed that they were descendants of the illustrious Rāstrakūta dynasty (RVM I. 34-35, 2. I-28). The Rāstrakūtas controlled much of central, western and southern India from the middle of eight to the end of tenth centuries CE. The Rāthod Rājpūts of Jodhpur also claimed Rāṣtrakūța inheritance. Both Bāgula and Rāṭhọ̣ dynasties share the same Gautama gotra and espoused similar traditions of inheritance (for instance, see: Abū al-Fażl, $\bar{A}$ 'ìn-i Akbarī, translated by H. Blochmann and H. S. Jarrett (Calcutta, I873-I894), vol. 2, p. 27I; J. Tod, Annals and Antiquities of Rajasthan (reprint London, I950), p. 9 ff; M. A. Sherring, Hindu Tribes and Castes as Represented in Benares, vol. I (Calcutta, Bombay and London, I872), pp. $58,88, \mathrm{I} 26, \mathrm{I} 44, \mathrm{I} 84,206)$. But historians question the veracity of these narrative traditions. There is a paucity of conclusive evidence to show that the Bāgulas were connected to Rāṭoḍs through a common Rāsțrakūṭa ancestry. For a more elaborate discussion of their common genealogies, see: J. L. de Bruyne, Rudrakavi's Great Poem of the Dynasty of Rāstraudha: Cantos 1-13 and 18-20 (1968), pp. X-I2; V. S. Bhargava, Marwar and the Mughal Emperors (Delhi, I966), p. 4.

${ }^{3}$ Bāglāna is located in the Nashik district of Maharashtra today. On the history of Bāglāna, see: M. S. Naravane, A Short History of Baglan (Pune, I997); S. R. Sharma, Marāthā History Re-examined: 1295-1701 (Bombay, I944), p. 9; Imperial Gazetteer of India (Oxford, I908-09), vol. vi, p. I90 ff.; Abū al-Fażl, $\bar{A}$ '̄̄n-i Akbarī, translated by H. Blochmann and H. S. Jarrett (Calcutta, I873-I894), vol. 3, p. 43.

${ }^{4}$ Bāglāṇa became a tributary of the Mughal empire in I637, when Shāh Jahān, the Mughal emperor (r. I628I658), sent an army led by his son Aurangzeb to annex Bāglāna. It was merged in the Khandesh province. The king of Bāglāna was reduced to the status of a Mughal amir of 3,000 zat without any territorial deed (vatan jāgir) to his erstwhile kingdom. His son later converted to Islam and was granted the title of Daulatmand Khān, a rank of I, 500 zat and the territorial deed (vatan jāgìr) to a pargana in Khāndesh. See: John F. Richards, The Mughal Empire (Cambridge, I995), p. I 28.

${ }^{5}$ On the history and poetics of campū genres, see: C. R. Deshpande, Studies in Campū Literature (Delhi and Varanasi, I992); Chhavināth Tripāthī, Campū-Kāvya Kā Ālōcanātmaka Evam Aitihāsika Adhyayana, The Vidyabhawan Rashtrabhasa Granthmala 83 (Varanasi, I965). 
complete edition of his praise poems-DC, NKC, JC, KS/KC-does not exist. Among all extant manuscripts of Rudra's panegyrics, the Bühler collection provides the most complete edition of his poems. Consequently, these manuscripts serve as a primary historical source for exploring the relationship between Sanskrit poets and the Mughal Empire.

These three Bühler manuscripts have received considerable scholarly attention in the past because Rudra's writings are valuable sources for addressing some key issues in South Asian historiography - particularly, for appraising the relationship between Sanskrit poets and the Mughal empire, the interactions between Brahmin scholars and Muslim elites, and the presence of historical consciousness in Sanskrit literature. ${ }^{6}$ In grappling with these issues, previous studies have examined the handwritten content of the Bühler manuscripts with the intent of identifying and reconstructing the original writings of Rudra. Despite their attempts to salvage Rudra's literary oeuvre, the history of the material production, textual transmission and cultural reception of these three manuscripts remain largely unresearched and unexamined. Without a coherent understanding of how these manuscripts were produced, circulated, preserved, rediscovered and archived, neither the interpretation of their textual attributes nor the reconstruction of their literal content can be properly performed. This essay, therefore, traces the journey of the Bühler manuscripts from the hands of the original scribe to the modern archives and published editions. In doing so, it unpacks the diverse ways in which modern cataloguers, editors and scholars have analysed the physical features, textual content and reception history of the Bühler manuscripts. To develop its argument further, this essay reflects on the primary contexts of Rudra's creative imagination and the scribe's textual reproduction. It subsequently outlines the respective contributions of the poet and the scribe in the material production of manuscripts.

Based on a critical appraisal of handwriting, colophons, watermark and other textual attributes, this essay shows that the three Bühler manuscripts constitute a composite volume of an anthology of Rudra's pangyrics. ${ }^{7}$ All three manuscripts were copied by the same scribe who reproduced-deftly and faithfully-the content of his exemplar sometime between I 840 and I880. His exemplar, however, was a draft edition of several incomplete panegyrics that the poet had been composing simultaneously in praise of some prominent members

\footnotetext{
${ }^{6}$ For previous scholarship on Rudra's life and works, see fn. I.

${ }^{7}$ There is very little scholarship on the codicology of composite manuscripts produced in South Asia; see: Florinda de Simini, 'Śivadharma Manuscripts from Nepal and the Making of a Śaiva Corpus,' in One-Volume Libraries: Composite and Multiple-Text Manuscripts, edited by Michael Friedrich and Cosima Schwarke (Berlin/Boston, 20I6), pp. 233-286; Camillo Formigatti, 'Sanskrit Annotated Manuscripts from Northern India and Nepal,' ( $\mathrm{PhD}$ thesis, Hamburg University, 20II), pp. 26-39; Jeremiah Losty, The Art of the Book in India (London, I982). Scholars of European manuscript and book cultures have reflected more extensively on the codicology of composite manuscripts; see: Michael Friedrich and Cosima Schwarke (eds.), One-Volume Libraries: Composite and Multiple-Text Manuscripts (Berlin/Boston, 20I6) pp. I-26; Patrick Andrist, Paul Canart and Marilena Maniaci, La syntaxe du codex. Essai de codicologie structurale (Turnhout, 2013); Pamela Robinson, 'The Format of Books-Books, Booklets and Rolls,' in The Cambridge History of the Book in Britain, vol. ii, 1100-1400, edited by N. Morgan and R. M. Thomson (Cambridge, 2008); Peter Gumbert, 'Codicological Units: Towards a Terminology for the Stratigraphy of the Non-Homogenous Codex,' in Il codice miscellaneo. Tipologie e funzioni, edited by Edoardo Crisci and Oronzo Pecere (Cassino, 2004), pp. I7-42; Erik Kwakkel, 'Towards a terminology for the analysis of composite manuscripts,' Gazette du livre medieval (2002), pp. I2-19; Evans Murray, Rereading Middle English Romance: Manuscript Layout, Decoration, and the Rhetoric of Composite Structure (Montreal, I995); Pamela Robinson, "The "Booklet": Selfcontained units in composite manuscripts of the Anglo-Saxon period,' Anglo-Saxon England 7 (I980), pp. 23 I-238; Lynn Thorndike, 'The Problem of the Composite Manuscript,' in Miscellanea Giovanni Mercati (Città del Vaticano, I946), vol. 6. pp. 93-I04.
} 
of the Mughal elite. These crucial details about the three Bühler manuscripts were not known to scholars in the past. For want of a robust codicological analysis, previous studies have applauded the Brahmin poet for his literary prowess and held the scribe responsible for the "fragmentary" and "corrupt" condition of these manuscripts. This essay distances itself from such unwarranted privileging of a Brahmin poet and marginalisation of a skilled scribe. Instead, it seeks codicological and textual evidence in determining the roles played by the poet and the scribe in the production of the Bühler manuscripts. In the end, it reaffirms the value of codicological reflections in the fields of South Asian historiography and literary studies.

\section{A Muddled Rediscovery of Rudra Kavi}

When Simon Theodor Aufrecht (I 822-I907) published the inaugural volume of his Catalogus Catalogorum — an "alphabetical register" of Sanskrit works and authors - in I 89 I, he had already identified a poet named Rudra as the author of Bäbakhānacaritra. ${ }^{8}$ No other literary work of Rudra was then known to the cataloguer. The precise circumstances that led Aufrecht to rediscover both the poet and his Bäbakhānacaritra are unknown. To compile the first volume of Catalogus Catalogorum, he had consulted 56 catalogues and handlists of Sanskrit manuscripts. ${ }^{9}$ Yet not a single catalogue was cited in his entry on Rudra. Nor did he record the codicological details of any extant manuscript of Bābakhānacaritra. Save for the first volume of Catalogus Catalogorum, Rudra and Bābakhānacaritra did not reappear in any other of Aufrecht's bibliographic undertakings or scholarly work.

Aufrecht embarked upon the project of compiling Catalogus Catalogorum in I 889 when he "obtained his release from the duty of giving lectures" at University of Bonn. ${ }^{10}$ In the preceding decades, a large corpus of manuscripts had been procured by Martin Haugh (I 827I 876), Johann Georg Bühler (I 837-I898), Lorenz Franz Kielhorn (I840-I908), Peter Peterson (I847-I 899) and their associates in India. ${ }^{11}$ A substantial portion of their collections were subsequently dispatched to various libraries and archives in India and Europe. Hermann Georg Jacobi (I850-I937), who was appointed the professor of Sanskrit at the University of Bonn after Aufrecht's retirement in I889, described the Catalogus Catalogorum as "a grandly planned scientific work" that sought to provide a clear survey of "a quite unexpected wealth of manuscripts" recently obtained by Bühler and his collaborators. ${ }^{12}$ Given the scope of his project, Aufrecht regretted his "absence from the great centres of manuscripts and books", by which he meant "the libraries of Berlin and of the India Office in London". ${ }^{3}$ Nevertheless, since both the Government of India and his personal friends at the India

\footnotetext{
${ }^{8}$ Theodor Aufrecht, Catalogus Catalogorum (Leipzig, I89I), p. 528.

${ }^{9}$ Ibid., pp. iii-vii.

${ }^{10}$ Hermann Jacobi, 'Obituary Notices. Theodor Aufrecht,' translated from the Bonner Zeitung (7 April I907), no. 95, p. I6, in The Journal of the Royal Asiatic Society of Great Britain and Ireland (Oct 1907), p. I I24.

${ }^{11}$ Kris Manjapra, Age of Entanglement: German and Indian Intellectuals across Empire (Cambridge, Massachusetts, 20I4), pp. 23, 24-26, 28, 39-40, 50; Donald Clay Johnson, 'German Influences on the Development of Research Libraries in Nineteenth-Century Bombay,' The Journal of Library History 21.I (winter I986), pp. 2I 5-227; Julius Jolly, 'A Note on Bühler,' The Indian Antiquary 28.346 (December I899), pp. I-23; Moriz Winternitz, 'In Memorium Georg Bühler,' The Indian Antiquary 27.2 (I 898 ), pp. 337-386.

${ }^{12}$ Hermann Jacobi, 'Obituary Notices. Theodor Aufrecht,' translated from the Bonner Zeitung (7 April I907), no. 95, p. I6, in The Journal of the Royal Asiatic Society of Great Britain and Ireland (Oct I907), p. I I24.

${ }^{13}$ Theodor Aufrecht, Catalogus Catalogorum (Leipzig, I891), p. iii.
} 
Office Library favoured his encyclopedic project, he was readily granted access to their catalogues, handlists, records and manuscripts. ${ }^{14}$

After the India Office Library was founded in I798, its collections of Sanskrit manuscripts had multiplied steadily, and the library became a major repository of Sanskrit manuscripts by the end of nineteenth century. ${ }^{15}$ It had received Sanskrit manuscripts from several sources: Colonel Colin Mackenzie (I754-I82I), ${ }^{16}$ Henry Thomas Colebrooke (I765-I837), ${ }^{17} \mathrm{Sir}$ Charles Wilkins (I749-I836), John Taylor (d. I82 I), the Gaekwads of Baroda, ${ }^{18}$ John Faithfull Fleet (I847-I9I7), James R. Ballantyne (I8I3-I864), Arthur Coke Burnell (I840-I882), Rajah Sourindra Mohan Tagore (I 840-I9I 5), ${ }^{19}$ Brian Houghton Hodgson (I80I-I 894) ${ }^{20}$ and others. This archive was further enriched by a bill that the Government of India passed on 3 November I 868, whereby a budget of 25,000 rupees was reserved for the collection and preservation of Sanskrit manuscripts. This law enabled Bühler and his associates to acquire a collection of 2,876 manuscripts for government libraries and archives. ${ }^{21}$

When Aufrecht was preparing the first volume of the Catalogus Catalogorum, several Sanskrit manuscripts of the India Office Library, which Bühler and others deposited there, remained unidentified and uncatalogued. In the preface to his catalogue, Aufrecht complained, "bundles of Sanskrit manuscripts are scattered in public and private libraries of England without attracting any notice". ${ }^{22}$ Among the uncatalogued Sanskrit manuscripts that were then accessible to Aufrecht, two collections had been transferred by the Royal Asiatic Society to "the custody of the India Office" in July I876. Sir William and Lady Jones had gifted one of these collections to the Royal Asiatic Society, and Burjorjee Sorabjee Ashburner had donated the second collection. Neither collection contained a manuscript attributed to Rudra or associated with Bäbakhānacaritra. ${ }^{23}$

Bühler presented a significant collection of $32 \mathrm{I}$ manuscripts to the library in $1888 .{ }^{24} \mathrm{He}$ had collected these manuscripts during his long stint in India (Io February I863-I 8 September I880). ${ }^{25}$ A team of scholars-Julius Eggeling (I 842-I918), Ernst Windisch (I844-I9I 8),

\footnotetext{
${ }^{14}$ Ibid., p. iii; Donald Clay Johnson, 'German Influences on the Development of Research Libraries in Nineteenth-Century Bombay,' The Journal of Library History 2I.I (winter I986), pp. 2 I 5-227.

${ }^{15}$ Rajeshwari Datta, 'The India Office Library: Its History, Resources, and Functions,' The Library Quarterly: Information, Community, Policy 36.2 (I966), pp. I $34^{-\mathrm{I}} 39$.

${ }^{16} \mathrm{His}$ collection consists of I,I65 manuscripts which the colonel had procured in between I822 and I 833 (ibid., p. I39).

${ }^{17}$ Colebrooke donated 2,749 manuscripts to the library in I8 I9 (ibid., p. I34).

${ }^{18}$ They donated 507 manuscripts in I 809 (ibid., p. I34).

${ }^{19} \mathrm{He}$ donated I40 manuscripts in I902 (ibid., p. I39).

${ }^{20}$ Brian Houghton Hodgson donated several Buddhist Sanskrit Manuscripts to both the Royal Asiatic Society and the India Office Library. The latter received manuscripts in three separate instalments in I838, I845 and I864. His donations were merged into a singular collection of IO8 volumes (95 volumes of manuscripts and I 3 scrolls) in I92I.

${ }^{21}$ Donald Clay Johnson, 'German Influences on the Development of Research Libraries in NineteenthCentury Bombay,' The Journal of Library History 2I.I (winter I986), p. 2 I9.

${ }^{22}$ Theodor Aufrecht, Catalogus Catalogorum (Leipzig, I 89I), p. iii.

${ }^{23}$ Charles H. Tawney and F. W. Thomas, Catalogue of Two Collections of Sanskrit Manuscripts Preserved in the India Office Library (London, I903).

${ }^{24}$ Among the 32 I manuscripts that Bühler presented to the India Office Library, I 28 were old copies and I93 were modern copies of Indic manuscripts. He donated I 77 manuscripts in 20 I volumes to the Royal Library (Staatsbibliothek) in Berlin (Julius Jolly, 'A Note on Bühler,' The Indian Antiquary 28.346 (December I 899), p. 382). Bühler also purchased 485 manuscripts for the Berlin Library.

${ }^{25}$ Ibid., p. 8 .
} 
Ernst Anton Max Haas (I835-I882), Frederick William Thomas (I867-I956) and Arthur Berriedale Keith (1879-I944)—were in the process of compiling catalogues of Sanskrit manuscripts at the India Office Library, including those belonging to the Bühler collection. They published the first part of their catalogues in I 887. While Aufrecht was sorting out the titles and authors of Sanskrit works for the first volume of Catalogus Catalogorum, Eggeling also provided him with the "proof-sheets" of the second part of their unpublished catalogue. ${ }^{26}$ Although none of the catalogues compiled by Eggeling or his associates mention Rudra or his poems, Aufrecht, who had gained access to the Bühler collection of Sanskrit manuscripts at the India Office Library, found Rudra's manuscripts in that collection.

During his stay in India, Bühler had organised several manuscript search missions to different parts of South Asia. He recorded his experiences and findings in a series of reports that were submitted to the governing authorities in the 1870 s. $^{27}$ Unlike some of his predecessors, Bühler was able to foster an amicable relationship with traditional scholars, patrons and manuscript collectors. ${ }^{28}$ Above all, he meticulously planned his expeditions. For instance, he prepared "a union list of works owned by individuals and libraries in Bombay" and obtained all "lists of holdings of libraries in the presidency" to ensure that duplicates of previously procured items were not repurchased or reacquired. ${ }^{29}$ By all accounts, he was an accomplished procurer of Sanskrit manuscripts in India. However, he did not show much interest in compiling "accurate bibliographic description[s]" of his manuscript collections. $^{30}$

After his manuscript search missions were over, Bühler-following the cataloguing norms formulated by Franz Kielhorn — circulated a printed list of new acquisitions among various libraries in India and Europe. These handlists seldom delineated the codicological details of their manuscripts. Their bibliographic records usually consisted of only the authors and titles of the works. When Max Müller addressed an audience of the International Congress of Orientalists in I874, he noted that "the mere titles of the manuscripts whet our appetite but do not satisfy it". He wanted to "know more" about "books which are scarce and hitherto not known out of India". He appealed to cataloguers that they should provide "some information of the subject and its treatment, and if possible the dates of the author and those of writers quoted by [the author]". ${ }^{31}$ In this regard, he congratulated Aufrecht for compiling

\footnotetext{
${ }^{26}$ Theodor Aufrecht, Catalogus Catalogorum (Leipzig, I891), p. iv.

${ }^{27}$ Georg Bühler, Report on the Search for Sanskrit Manuscripts 1879/80-1894/95 (Bombay, I880-I90I), 8 vols; Georg Bühler, Detailed Rport of a Tour in Search of Sanskrit Mss. Made in Kásmir, Rajputana, and Central India (London, I877); Georg Bühler, R. G. Bhandarkar and A. V. Kathavate, Report on Sanskrit Manuscripts, 1874-75 (Bombay, I 874-75); Georg Bühler, R. G. Bhandarkar and A. V. Kathavate, Report on Sanskrit Manuscripts, 1872-1873 (Bombay, I872-73); Franz Kielhorn and Georg Bühler, Reports from Drs. Kielhorn and Bühler on the search for Sanskrit mss. in the Bombay presidency, 1870/71, 1872/73-1874/75 (Bombay, I87I-75), 4 vols.

${ }^{28}$ Donald Clay Johnson, 'German Influences on the Development of Research Libraries in NineteenthCentury Bombay,' The Journal of Library History 21.I (winter 1986), pp. 213, 216-2 I 8.

${ }^{29}$ Ibid., p. 21 8-2 I9.

${ }^{30}$ Donald Clay Johnson, who investigated the role of three Germans-Martin Haug, Georg Bühler and Franz Kielhorn - in the development of modern research libraries in the nineteenth century, contends that Kielhornunlike Bühler - had "assumed the role of maintaining accurate bibliographic description of the discoveries in India” (ibid., p. 223).

${ }^{31}$ These quotations from Müller's lecture appear in Donald Clay Johnson's essay (ibid., p. 224). The original lecture was published in Public Proceedings No. 2053, December 1881 by the Government of Bombay, Education Department.
} 
a detailed catalogue of Sanskrit manuscripts acquired by the Bodleian Library. ${ }^{32}$ Bühler, unlike Aufrecht, was less invested in the preparation of detailed catalogues, and his handlists hardly ever ventured into the codicological details of manuscripts. Furthermore, although his reports elaborately described his quest for manuscripts in different parts of India, none of his anecdotes document his discovery of the three manuscripts of Rudra that currently bear the shelf marks of Bühler 70a, $70 \mathrm{~b}$ and $70 \mathrm{oc}$ in the India Office collection of the British Library.

The early history of the rediscovery of the manuscripts of Rudra is thus mostly inaccessible today. For instance, it is still unknown who first chanced upon the manuscripts of Rudra in the latter half of the nineteenth century. Were these manuscripts uncovered by Aufrecht, Bühler, a traditional pandit, a professional kāyastha, a local zamindar or an affluent bibliophile? Where were these manuscripts originally copied and stored? Who identified the primary title of Rudra's literary work as Bābakhānacaritra? Was it mentioned by Rudra himself; was it supplied by Aufrecht; was it identified by Bühler; or was it proposed by one of their Indian collaborators? Moreover, what were the bases for the identification of the title, authorship and genre of these manuscripts? Were textual scholars relying solely on the colophons of manuscripts; were they examining the formulaic ending of each chapter; or were they looking for some self-referential phrases within the body of each chapter? If their manuscripts were fragmentary and corrupt, how did scholars approach the problem of textual recovery? How did they reimagine the fuller version of a literary work when only part of the complete work was available to them?

If Aufrecht had read one of the three Bühler manuscripts at the India Office Library, one wonders why he failed to identify other literary works of Rudra that were present in the same collection. On the other hand, if Bühler himself rediscovered and identified the content of the three manuscripts, it is strange that his official accounts and reports on various kâvya manuscripts are devoid of any reference to Rudra and his literary works. Given the paucity of documentary evidence regarding both the manuscript search missions and the methodology of orientalists, codicologists and bibliographers in the nineteenth century, a contemporary historian will never be able to find conclusive answers to these questions.

\section{Recurring Rediscoveries of Rudra Kavi}

Early in the twentieth century, a manuscript of Rudra's Rāstrauḍavamśamahākāvya (RVM) was "accidentally” rediscovered by Paṇịta R. Anantakṛṣna Śāstrī (I 866-I950) in the collection of "a Deccani Brahmaṇa" in Baroda. ${ }^{33}$ Śāstrī, who had honed his codicological and bibliographic skills in the company of Gustav Solomon Oppert (I 836-I908) at the Government Oriental Manuscripts Library in Madras, was an avid collector of manuscripts. In an issue of

\footnotetext{
${ }^{32}$ Although Max Müller praised Aufrecht for his "excellent catalogue", the bibliographic scope of Catalogus Catalogorum suffers from precisely the kind of problems Müller had raised in his I874 lecture. Aufrecht was aware of the limitations of "an alphabetical register of Sanskrit works and authors". The rich history of Sanskrit textual production makes it impossible for a lone scholar to do more than what Aufrecht could accomplish in Catalogus Catalogorum. In his catalogue of Bodleian Library and the Library of Trinity College, Aufrecht's codicological description of Sanskrit manuscripts is more rigorous and insightful. See: Theodor Aufrecht, Arthur Berriedale Keith and Moriz Winternitz, Catalogus codicum manuscriptorum sanscriticorum in Bibliotheca Bodleiana (Oxford, I859I909), 3 vols; Theodor Aufrecht, A Catalogue of Sanskrit Manuscripts in the Library of Trinity College (Cambridge, I 869).

${ }^{33}$ Embar Krishnamacharya (ed.), Râshtrauḍhacaṇśakâvya of Rudrakavi (Baroda, I9I7), p. xxi.
} 
The Theosophist, a magazine published by the Theosophical Society of Madras, an editor called his "official reports" of manuscript search missions "exceptionally interesting and instructive" and lauded his "special talent for collecting MSS. in South Indian villages".34 When the compilation project of the New Catalogus Catalogorum was inaugurated "in the last week of November I935", the four volumes of Śāstrī’s "diary" that he had deposited at the Catalogus Catalogorum Office in Madras served as one of the primary sources for the new compendium. ${ }^{35}$ His diary, comprised of three parts, reveals his approach to the study of manuscripts, codicology and bibliography. Although Śāstrī was a prolific discoverer of manuscripts, his codicological investigation never went beyond a minimalist physical description of manuscripts and his interests in cataloguing were limited to the preparation of lists of authors and titles. Consequently, his diary offers no new information about the extant manuscripts of Rudra. ${ }^{36}$

After collecting thousands of manuscripts for the Adyar Library between I892 and I90 I and for the Mysore Government Oriental Manuscripts Library between I9O2 and I9II, Sāstrī joined the Oriental Institute of the Maharaja Sayajirao University of Baroda in I9I 2. ${ }^{37}$ In I917, Embar Krishnamacharya published a diplomatic edition of the RVM manuscript that Śāstrī had found in the house of the Deccani Brahmin mentioned earlier. ${ }^{38}$ This chronology implies that Śāstrī must have chanced upon this manuscript sometime between I9I2 and I9I7. The diplomatic edition of the RVM manuscript was published as the fifth number of the Gaekwad's Oriental Series, an endowment of the Maharaja Gaekwad of Baroda, and it contained an elaborate introductory essay on the life and works of Rudra by Chimanlal Dahyabhai Dalal (I88 I-I9I 8). ${ }^{39}$

In addition to the Baroda manuscript, both Krishnamacharya and Dalal were aware of yet another manuscript of Rudra that had been found in Nashik recently. According to Dalal,

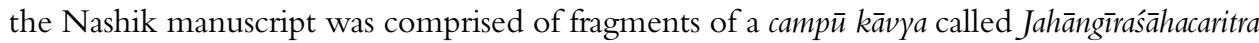
(JC) that Rudra had composed in praise of Jahāngīr (r. I605-I627). While evaluating the literary oeuvre of Rudra, neither Dalal nor Krishnamacharya made any reference to the findings of either Aufrecht or Bühler. They were apparently unaware of the three Bühler manuscripts of Rudra's panegyric poems that were then housed at the India Office Library. So,

\footnotetext{
34، General Report of the Twenty-Fifth Anniversary and Convention of the Theosophical Society, held at Benares, India, December 27th and 28th, I900, With Official Documents,' Supplement to the Theosophist (September I90I), p. I I (Reprinted in H. S. Olcott, The Theosophist, A Magazine of Oriental Philosophy, Art, Literature \& Occultism (Adyar, I90I), vol. xxii, p. 796).

${ }^{35}$ K. S. Rāmaswāmī Sāstrī, A Descriptive Catalogue of manuscripts at the Oriental Institute, Baroda (Baroda, I937), pp. v, x.

${ }^{36}$ See the entry on Rudra in the New Catalogus Catalogorum, (ed.) Siniruddha Dash (Madras, 20I I), vol. xxv, p. I34.

${ }^{37}$ After Baroda, Śāstrī travelled to Shanti Niketan in 1922 and continued to collect manuscripts in north and east India. He travelled to Europe in I934. The precise date of his departure and return are unclear. It seems he joined the New Catalogus Catalogorum project after returning from Europe.

${ }^{38} \mathrm{~A}$ diplomatic edition reproduces the literal content of a manuscript without comparing or collating it with other extant manuscripts of the same text. This main goal of a diplomatic edition is to recreate the text of the original manuscript with as much fidelity as is possible within the limits of modern typography. I discuss the differences between diplomatic and critical editions of a literary work later in the essay.

${ }^{39}$ For a brief biography of Chimanlal Dahyabhai Datta, see: Amresh Datta (ed.), Encyclopaedia of Indian Literature (New Delhi, I987), pp. 837-838; B. J. Sandesara, 'Shri C. D. Dalal, First Editor and Principal Organiser of the Gaekwad's Oriental Series,' Maharaja Sayajirao University of Baroda, Oriental Institute, Journal I2 (December I962), pp. I84-I86; Newton Mohun Dutt, Baroda and Its Libraries (Baroda, I928), Chapter iv, pp. 40-4I.
} 
Bābakhānacaritra was in all probability unknown to them. Even though they had noticed that several verses of the $R V M$ were repeated in the $J C$, they did not consider it necessary to explain the bases of their identification of the name, content and purpose of the fragmentary Nashik manuscript.

In I940, Har Dutt Sharma published his brief essay "The Poet Rudra and His Works" in a volume dedicated to A. C. Woolner (1878-1936). Sharma criticised Dalal for both failing to identify the textual composition of the Nashik manuscript and for ignoring the prior findings of Bühler. According to Sharma, Dalal was led to believe that the Nashik manuscript contained the JC because he had not consulted the three Bühler manuscripts listed in the catalogue of the India Office Library. Sharma questioned Dalal's reading and identification of the JC and wryly remarked, "But, it seems that Mr. Dalal never came across this work". 40

In contrast to the findings of Dalal and Krishnamacharya, Sharma "had come across the descriptions of not only one work but three works composed by Rudra". ${ }^{41}$ To rectify Dalal's incorrect identification of Rudra's literary oeuvre, Sharma quoted "relevant extracts" from these three Bühler manuscripts and concluded that Rudra, in addition to composing

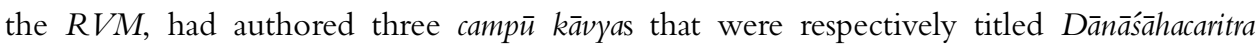
(DC), Nabābakhānacarita (NKC) and Kìrtisamullāsa (KS). Furthermore, based on six extracts found in Ms. 7304 (Bühler 7ob), he argued that the NKC was actually "a panegyric upon the Emperor Jehāngir, composed in I609 A.C. in three ullāsas". ${ }^{42}$

In his criticism of Dalal and Krishnamacharya, Sharma had justifiably raised two fundamental codicological and textual issues pertaining to the appraisal of Rudra's literary oeuvre: first, the misattribution of the textual content of the Nashik fragments, and second, the improper assessment of the prior reception of Rudra's works. Nevertheless, an unjust judgemental tenor and methodological opaqueness characterised Sharma's criticism of other scholars. If Dalal and Krishnamacharya had not consulted the catalogue of the Bühler collection, Sharma, too, had ignored the Nashik fragment. He was obviously wrong in assuming that Dalal "never came across" the JC. If Dalal and Krishnamacharya had not read and compared the Nashik fragments of the JC and the Baroda manuscript of $R V M$, how did they identify the verses recurring in both literary works? Sharma did not pay attention to the list of common verses that Dalal and Krishnamacharya mention on the very first page of their diplomatic edition of the $R V M{ }^{43}$ Furthermore, Sharma did not provide any documentary or circumstantial evidence to support his claim that the three manuscripts of the India Office catalogue were rediscovered and identified by Bühler himself and not by his colleagues, collaborators and informants. Since Sharma had not consulted the Catalogus Catalogorum, he too remained unaware of another key issue: why and how was the Bābakhānacaritra of Aufrecht connected to the Nabābakhānacarita of the Bühler collection? In his brief critical inquiry, Sharma did not re-examine the findings of previous collectors of Sanskrit manuscripts. Moreover, his identification of the proper subject of Bühler 7ob (Ms. 7304) would be categorically rejected by later scholars.

\footnotetext{
${ }^{40}$ Har Dutt Sharma, 'The Poet Rudra and His Works,' in Woolner Commemoration Volume, (ed.) Mohammad Shafi (Lahore, I940), p. 24I.

${ }^{41}$ Ibid., p. 24I.

${ }^{42}$ Ibid., p. 242. A.C. stands for "After Christ," which is rendered as CE (Common Era) today.

${ }^{43}$ Embar Krishnamacharya (ed.), Râshtrauḍhacaṇsakâvya of Rudrakavi (Baroda, I9I7), p. i.
} 
In I952, V. W. Karambelkar revisited the Nashik manuscript, which was now housed at Nagpur University. ${ }^{44}$ The university instituted its Manuscripts Department on I4 April I945. Karambelkar was appointed as its first Manuscript Officer on I June I946. Between I4 April I945 and I June I946, Y. K. Deshpande was responsible for procuring manuscripts for the newly founded department. Deshpande was able to acquire about I,500 manuscripts for the library, out of which I,OoO were purchased from the University of Nashik. ${ }^{45}$ The Nashik manuscript became the property of Nagpur University, which enabled Karambelkar to complete a study of Rudra's NKC.

While Karambelkar was writing his essay "Nābābakhānakhānānacaritam” for The Indian Historical Quarterly, his colleague Deshpande came across another incomplete manuscript of Rudra in Pune. ${ }^{46}$ Deshpande, who was aware of Karambelkar's ongoing research "secured" it for him. Karambelkar was thus able to compare the Pune and Nagpur manuscripts. ${ }^{47}$ When Karambelkar completed his brief essay on the NKC, it was published in a special issue of Nāgarì Pracārin̄i Patrikā in $1952 .{ }^{48}$ In the essay, he noted that the Bäbakhānacaritra in the Catalogus Catalogorum of Aufrecht "must be a mistake for Nabābakhānacaritam noted in the India Office Catalogue (No. 7304)". 49 However, he did not provide evidence for his assertion. He subsequently dismissed Har Dutt Sharma's claim that the NKC eulogised Jahāngīr. Instead, he declared, "The $N K C$ is in praise of Rahim, not of Jehangir." 50

In the long drama of recurring rediscoveries and speculative identification of Rudra's manuscripts, the publication of the Works of Rudra of the Court of Pratapsimha by Jatindra Bimal Chaudhuri in I959 constitutes a climactic moment. After completing his doctoral studies at the University of London, Chaudhuri published a revised edition of the India Office Catalogue of Sanskrit Books in I938. Prana Natha had commenced this project in I924, and, after two academic stints at the India Office Library-first, between I924 and I927, and later, between I93 I and I932- he left the catalogue incomplete. Chaudhuri restarted the project of cataloguing Sanskrit works in I 934 and published the first volume of the catalogue in 1938. Apart from engaging with codicological, bibliographic and textual studies, Chaudhuri was intellectually committed to exploring the "Muslim patronage to Sanskrit

\footnotetext{
${ }^{44}$ Nagpur University Ms. Acc. No. 582 (folios 3-22; Io inches x 4-1/2 inches; dark-yellow paper; legible handwriting). See: V. W. Karambelkar, 'Nabābakhānakhānacaritam,' The Indian Historical Quarterly, (ed.) Narendranath Law, xxviii (I952), p. 242 (footnote 6).

${ }^{45}$ V. W. Karambelkar, Catalogue of Sanskrit Manuscripts in the Nagpur University Library (Nagpur, I958), p. Io.

${ }^{46}$ The current whereabouts of the Pune manuscript remain unknown. According to Karambelkar, the Pune manuscript was made up of Io folios (8 inches x 4.5 inches), and although its content was incomplete, the handwriting was clear (ibid., p. 242, footnote 6). However, no manuscript with such features appears in the catalogues and handlists of the Bhandarkar Oriental Research Institute, Bharat Itihas Samshodhak Mandal and Vaidik Samsodhan Mandala in Pune. This manuscript is not found in the catalogues of the Asiatic Society of Bombay, nor in the library of the K. R. Cama Oriental Institute. See: H. D. Velankar, A Descriptive Catalogue of Sariskrta And Präkrta Manuscripts in the Library of The Bombay Branch of the Royal Asiatic Society (Bombay, I926-30), 4 vols; Ervad Bomanji Busserwanji Dhabhar, The K. R. Cama Oriental Institute: Catalogue (Bombay, I923).

${ }^{47}$ V. W. Karambelkar, 'Nabābakhānakhānacaritam,' The Indian Historical Quarterly, (ed.) Narendranath Law, xxviii (I952), p. 242.

${ }^{48}$ V. W. Karambelkar, 'Nabābakhānakhānacaritam,' Nāgarīpracāriṇ̄ Patrika (Vārāṇas̄i, 2008 Samvat/I952), Kéśava Smṛti Arika, pp. 297-298.

${ }^{49}$ V. W. Karambelkar, 'Nabābakhānakhānacaritam,' The Indian Historical Quarterly, (ed.) Narendranath Law, xxviii (I952), p. 240.

${ }^{50}$ Ibid., p. 242.
} 
learning", 51 and he published several monographs and editions to show how Sanskrit literature had flourished under Muslim patronage. ${ }^{52}$ The title page of his Works of Rudra declares that the camp $\bar{u}$ kâa yas of Rudra have been "critically edited for the first time from unique Mss". ${ }^{53}$ Indeed, its publication in I959 was a milestone in the study of Rudra's works and manuscripts.

The three panegyric poems included in the Works of Rudra are Navāvakhānakhānānacarita (NKC), Dānaśāhacarita (DC) and Khurammacarita (KC). Five years earlier, in 1954, Chaudhuri had already published his edition of the NKC in the book Khān Khānān Abdur Rahim (1557 A.D. -1630 A.D.) and Contemporary Sanskrit Learning. He reproduced his 1954 edition of the NKC in his 1959 book, Works of Rudra, without any alteration. In the introduction of the I954 edition, Chaudhuri informed his readers that "only one manuscript" of the NKC, Ms. 7304 (Bühler 7ob), was extant and that it was housed at the Commonwealth Relations Office (CRO) Library in London. ${ }^{54} \mathrm{He}$ further noted that two other manuscripts of Rudra's campū kāovas — one of Kìrtisamullāsa, Ms. 7303 (Bühler 7oc), and the other of Dānaśāhacarita, Ms. 7089 (Bühler 70a) — were held by the India Office Library. His assertion was inconsistent with those of Aufrecht, Bühler, Sharma and Karambelkar, all of whom had located the three Bühler manuscripts at the India Office Library. While it is true that the CRO was administering the India Office Library in 1954, they did not institute an independent library or repository for relocating the archival collections of the library. Hence, they could not have moved Bühler 7ob-leaving behind Bühler 70a and 70c - from the India Office Library to another repository. ${ }^{55}$ When Chaudhuri reproduced the critical apparatus and codicological description of his 1954 edition in his 1959 book, he removed the sentence about the CRO Library and its acquisition of Ms. 7304 (Bühler 7ob). ${ }^{56}$ But he insisted that there was only one extant manuscript of the NKC. He was apparently unaware of the existence of Nagpur and Pune manuscripts discovered by Deshpande and examined by Karambelkar.

In the I940s, Chaudhuri had regularly corresponded with P. K. Gode, the curator of the Bhandarkar Oriental Research Institute, who provided him with the copies of several "unique" manuscripts that were only available in the Bombay Presidency: "Subhāsitahārāvatī of Hara Kavi, Padyaveṇ̄ of Veṇīdatta, Sabhyālaikaraṇa by Jagajjīvana, Payāmrtataranigin̄̄ of

\footnotetext{
${ }^{51}$ This is also the title of one of his books. See: Jatindra Bimal Chaudhuri, Muslim Patronage to Sanskritic Learning (first published in 1954, reprint New Delhi, I98I).

${ }^{52}$ Jantindra Bimal Chaudhuri, The Nripati-niti-garbhita-vritta or Farruk-siyar-carita of Laksmipati of Kumaun, CourtPoet of Jagaccandra (Calcutta, I959); Khān Khānān Abdur Rahim (1557 A.D.-1630 A.D.) And Contemporary Sanskrit Learning (Calcutta, I954); The Sangìta-Mālikā of Mahammad Shāh (Calcutta, I948); The Ābdullāh-Carita by Kajșmidhara (Calcutta, I947); The Rāmacandra-Yaśậ-Prabandha of Govinda-Bhaț̣a Alias Akbarīya-Kālidāsa (Calcutta, I946).

${ }^{53}$ Chaudhuri confuses the distinction between diplomatic and critical editions of a text. I discuss this issue later in the essay. See fn. 38 too.

${ }^{54}$ Jatindra Bimal Chaudhuri, Khān Khānān Abdur Rahim (1557 A.D.-1630 A.D.) And Contemporary Sanskrit Learning (Calcutta, I954), p. 56.

${ }^{55}$ The Commonwealth Relations Office (renamed the Commonwealth Office in I968) began administering the archival holdings of the Indian Records Section (later known as the India Office Records) as well as the India Office Library after the independence of India and Pakistan on I4-I5 August I947 and Burma on 4 January I948. The Office did not institute a new library for itself; it merely took over the responsibility of administering older libraries and archival collections. Hence, although the administrative organisation of the India Office Library was altered at different points in history and it was eventually merged in the British Library in I982, it did not disperse the manuscript collections of the India Office Library, which have remained mostly intact ever since the library was instituted in the nineteenth century.

${ }^{56}$ Ibid., pp. 56-58; Jatindra Bimal Chaudhuri, Works of Rudra of the Court of Pratapsimha (Calcutta, 1959), pp. $2 \mathrm{I}-22$.
} 
Haribhāskara, Āsafavilāsa of Jagannātha, and so on". ${ }^{57}$ While Chaudhuri refrains from disclosing the complete list of manuscripts he had obtained from Pune, it is unclear why he did not inquire with Gode about the copies of the Nagpur and Pune manuscripts, particularly as he was preparing his critical edition of the NKC around this time. Furthermore, since Chaudhuri did not account for the writings of Sharma and Karambelkar, it seems he was oblivious of their views and debates about Bühler 70b (Ms. 7304). In I940, Sharma had drawn attention to Bühler's findings, which led him to conclude that the NKC was a panegyric on Jahāngīr. Twelve years later, in I952, Karambelkar disputed Sharma's claim about who was being praised in the NKC. Furthermore, Karambelkar pointed out that Aufrecht had misidentified Bühler $7 \mathrm{ob}$ (Ms. 7304) as Bābakhānacaritra and that Bühler had rightly identified it as Nabābakhānakhānacarita.

Without making any reference to the ongoing discussions among Sharma, Deshpande and Karambelkar, Chaudhuri espoused a very different view of the reception history of the Bühler manuscripts. In his writings on Rudra, Chaudhuri did not discuss the findings of Aufrecht and Bühler, nor did he find any ground for relating or discarding the nominal differences between Bābakhānacaritra and Nabābakhānakhānacarita. More importantly, he narrated a novel account of how the NKC came to be associated with Jahāngīr and not with Raḥim. According to Chaudhuri, this idea was not forged by Aufrecht, Bühler or Sharma, rather it was propounded by Arthur Berriedale Keith. In his 1954 book, Khān Khānān Abdur Rahim (1557 A.D.-1630 A.D.) and Contemporary Sanskrit Learning, Chaudhuri held Keith responsible for propagating the claim that "the Nabāb-Khān-Khānān-carita was a panegyric of Emperor Jahangir". ${ }^{58}$ It was the first time since the manuscripts of Rudra were rediscovered in the latter half of nineteenth century that Keith was being held responsible for misreading and misidentifying the NKC. Chaudhuri, however, was confident about his findings, and he reiterated his stern criticism of Keith in his I959 book, Works of Rudra.

\section{Reification of Popular Perception}

Nine scholars examined the manuscripts of Rudra between I89I and 1959: Simon Theodor Aufrecht, Johann Georg Bühler, Arthur Berriedale Keith, R. Anantakrṣṇa Śāstrī, C. D. Dalal, Embar Krishnamacharya, Har Dutt Sharma, V. W. Karambelkar and Jatindra Bimal Chaudhuri. They all expressed divergent views about the manuscripts and the literary works of Rudra. None of them had fully explored the findings and observations of their predecessors, and none of them had direct access to all the surviving manuscripts of Rudra. Their aims, principles and methods of codicological analysis and textual interpretation varied, and their professional and intellectual interests differed. While most of them still grappled with some of the basic physical and textual details of the manuscripts, they exercised no restraint in producing a set of unsubstantiated claims about the nature, content and meaning of these manuscripts. Chaudhuri reified many of these unfounded generalisations and his claims were readily accepted by later scholars, politicians and social activists.

\footnotetext{
${ }^{57}$ Jatindra Bimal Chaudhury, Muslim Patronage to Sanskritic Learning (reprint New Delhi, I98I), p. iv.

${ }^{58}$ Jatindra Bimal Chaudhuri, Khān Khānān Abdur Rahim (1557 A.D.-1630 A.D.) And Contemporary Sanskrit Learning (Calcutta, I954), p. 57.
} 
In the wake of the independence movement of India, both scholarly and general readership appreciated works that highlighted communal and religious harmony among Hindus and Muslims in South Asia. In the preface of his book on the contributions of 'Abd al-Rahīm Khān Khānān, Chaudhuri honestly and justly noted:

Works of this type, Sanskrit treatises composed by Muslim scholars and purposely written in Sanskrit-Persian at once reveal the main aim of the authors viz. development of a Cultural unity between the Hindus and Muslims. Instances may be multiplied for showing that Hindus and Muslims in those days lived very peacefully side by side, in a really fraternal manner. ${ }^{59}$

That Rudra had praised members of the Muslim elite would not only affirm "cultural unity" among Hindus and Muslims, it would also enhance the value of his poetic oeuvre. By letting the political context speak for the text, Chaudhuri evaded several codicological and textual issues that would have complicated the critical appraisal of manuscripts attributed to Rudra and similar literary actors in South Asia.

Since contemporary scholars, readers and political leaders were sympathetic and supportive of Chaudhuri's intellectual leanings and political endeavours, his books were widely circulated in South Asia. In 1942, the Government of United Bengal purchased "a large number of copies of the first edition [of Muslim Patronage to Sanskritic Learning] for distribution all over India and outside". ${ }^{60}$ Maulana Abul Kalam Azad, the first Minister of Education of the government of independent India, allocated additional funds to the Prācyavāṇ̄ Mandir - an "Institute of Oriental Learning" founded and administrated by Chaudhuri himselfin order to facilitate the publication of books relating to the "Muslim Patronage to Sanskritic Learning". When the first edition of the NKC was published in I954, the Government of India paid for "half the cost of [its] publication". ${ }^{61}$ His Muslim Patronage to Sanskritic Learning was republished by the Idārah-i Adabiyāt-i Dehlī in I98I, and his edition of Nābābakhānakhānānacaritam was reprinted by the Akhil Bhāratīya Muslim Sanskrit Sanrakṣan Evam Prācya Śodha Sansthān, Vārānasī, in 2007. Thus, Chaudhuri played a major role in popularising the literary oeuvre of Rudra, and his 1959 book, Works of Rudra, became an "authoritative" edition of Rudra's panegyric poems. ${ }^{62}$

After the publication of Chaudhuri's critical edition in I959, no new study of Rudra's poetic oeuvre surfaced until the end of the last century. Given this lull in interest, Rudra

${ }^{59}$ Ibid., p. iv.

${ }^{60}$ Ibid., p. iii.

${ }^{61}$ Ibid., p. v.

${ }^{62}$ There is no ethical justification for misreading, misrepresenting and misinterpreting historical evidence in response to the unjust and violent politics of the present. Irrespective of how people behaved and thought in the past, one is obligated to reform the issues of the present. The crisis of the present may or may not be related to the incongruities of the past. In The Problem of Slavery as History, Joseph C. Miller rightly cautions historians against what he called the "perils of presentism" and the "temptations of teleology". Instead of "contemplat[ing] what people in the past might or should have done", he argues, "historians focus on what people actually did, insofar as we have the evidence to know about it". Hence, "the stories [historians] tell are not always pretty. Nor should historians attempt to animate these abstractions, to make religions or nations or slavery itself, into quasi-anthropomorphic actors" (Joseph C. Miller, The Problem of Slavery as History: A Global Approach (Yale, 2012), p. 8). These "quasi-anthropomorphic actors" unfortunately played a major role in the production and circulation of Chaudhuri's edition of the Works of Rudra. 
was almost forgotten by the academic world in the latter half of twentieth century. Consequently, when the Akhil Bhāratīya Muslim Sanskrit Sanrakșaṇ Evaṃ Prācya Śodha Sansthān in Vārānasīinaugurated a new book series to shed light on some rare and inaccessible Sanskrit literary works (ajñāt evam durlabh krti prakāśan mālā), Rudra appeared a worthy choice for republication. For the first volume of their series, Pratāp Kumār Miśra was commissioned to produce a Hindi edition (sampādan) and translation (anuvād) of the NKC.

In 2007, Miśra published his book under the eponymous title of Navābakhānakhānācaritam. While discussing the critical apparatus (pandulipi paricay) of his book, Miśra admitted that he was merely reproducing the text compiled by Chaudhuri. ${ }^{63}$ In his own defence, as he recounted, he had repeatedly requested that Nagpur University provide him access to Rudra's manuscripts, but the university refused. Consequently, he had to resort to the published editions of Chaudhuri and Karambelkar. While translating the $N K C$ into Hindi, Miśra was faced with several codicological and textual problems in both Chaudhuri's and Karambelkar's editions. ${ }^{64}$ But the scholarly credentials of Chaudhuri were firmly established in his mind, and he sincerely believed that Chaudhuri had presented a "flawless reading" (śuddhapattha) of the NKC manuscripts and that any textual problems were due to the "corrupt" condition of the manuscript (ásuddha pandulipi). ${ }^{65}$

In 20I2, Audrey Truschke re-examined the manuscripts of Rudra in her doctoral dissertation "Cosmopolitan Encounters: Sanskrit and Persian at the Mughal Court". 66 In her exploration of the poetic oeuvre of Rudra, she refrained from probing the long reception history of the Bühler manuscripts. She identified some flaws in the critical apparatus of Chaudhuri's Works of Rudra ${ }^{67}$ and voiced her disagreements with Karambelkar's readings. ${ }^{68}$ Her nuanced analysis of Rudra's poetics and politics followed a line of argument that Chaudhuri had inaugurated in the I950s. ${ }^{69}$ Most of her citations from the NKC, however, retained the same verse sequence and textual content that Chaudhuri had reordered and reproduced in his edition. In addition to Chaudhuri's edition, she also consulted a "single, fragmentary" manuscript of Jahāngìracarita held at the Baroda Oriental Institute (Ms. 576I), which, she then believed, had "never been explored by modern scholars". ${ }^{70}$ That both Miśra and Truschke relied extensively on Chaudhuri's work shows how some of his basic assumptions about the identification, textual reconstruction and interpretation of the Bühler manuscripts have remained uncontested until today.

${ }^{63}$ Pratāp Kumār Miśra, Śrimad-Rudrakavi-Viracitam Navābakhānakhānā-Caritam (Vārāṇas̄i, 2007), p. 6.

${ }^{64}$ Ibid., part ii, pp. I, 3, 4, 5, 6 .

${ }^{65}$ Ibid., p. 6.

${ }^{66}$ Audrey Truschke, 'Cosmopolitan Encounters: Sanskrit and Persian at the Mughal Court,' (PhD dissertation, Columbia University, 20I2), pp. 39, 72-8I, 330-333. Truschke has presented her findings in subsequent publications: Audrey Truschke, Culture of Encounters: Sanskrit at the Mughal Court (New York, 2016), pp. 65, 8I-88, I97198, 200; Audrey Truschke, 'Regional Perceptions: Writing to the Mughal Court in Sanskrit,' in Cosmopolitismes en Asie du Sud: Sources, itinéraires, langues (XVI - XVIII siècle), (eds.) Corinne Lefevre, Ines G. Županov and Jorge Flores (Paris, 20I5), pp. 25I-273.

${ }^{67}$ Audrey Truschke, 'Cosmopolitan Encounters: Sanskrit and Persian at the Mughal Court,' (PhD dissertation, Columbia University, 20I2), p. 72 (footnote I68), p. 79 (footnote I93).

${ }^{68}$ Ibid., p. 78

${ }^{69}$ Ibid., p. 29

${ }^{70}$ Ibid., p. 73 . 


\section{Assembling a Composite Volume}

Among the surviving manuscripts of Rudra's works, the Bühler collection-70a (Ms. 7089), 7ob (Ms. 7304) and 70c (Ms. 7303) - has played a pivotal role in shaping scholarship on the poet. These three manuscripts were the primary sources for Chaudhuri's Works of Rudra. On the title page of his book Chaudhuri declared that he had critically edited the panegyric poems of Rudra "for the first time" from "unique" manuscripts of each literary work. In reality, he was neither producing a critical edition nor perusing unique manuscripts of Rudra.

If the Bühler manuscripts were, indeed, unique copies of Rudra's panegyric poems, then Chaudhuri's book should be identified as a diplomatic — not a critical—edition. ${ }^{71}$ A diplomatic edition merely recasts the content of a unique manuscript of a work. ${ }^{72}$ For compiling a critical edition, scholars compare two or more manuscripts of a work and thereby determine the "base" text (akin to the "ur" text or the âdarśa in Sanskrit). The base text is reproduced in critical edition with a considerably high degree of fidelity. The variants found in different manuscripts - especially when these variants illuminate diversity in grammatical, orthographical, literary and scribal norms - are duly represented and contextualised. ${ }^{73}$ In his edition of the panegyric works of Rudra, Chaudhuri reproduced the content of a unique manuscript without attempting to compare it with other surviving manuscripts. ${ }^{74}$

Chaudhuri was confident that the Bühler manuscripts were unique copies of three independent panegyrics by Rudra. On the one hand, one could infer from his confidence that he was unaware of other manuscripts consulted by scholars in the past, for instance, those held at Nagpur (previously at Nashik), Pune and Baroda. While Chaudhuri may have been unaware of the manuscripts circulating in India, he was fully aware that the India Office Library in London held three manuscripts attributed to Rudra. In fact, at the end of his introductory essay about Rudra's work, he acknowledged the existence of two other manuscripts. ${ }^{75}$ But he somehow chose to exclude these two manuscripts from his critical

\footnotetext{
${ }^{71}$ The concept of "diplomatic edition" has been current among philologists and textual critics since before the late nineteenth century. In the I950s, when Chaudhuri was preparing an edition of Rudra's works, François Masai (I909-1979), an influential Belgian philologist, standardised the method of compiling diplomatic editions. To that end, Masai published an essay 'Principes et conventions de l'édition diplomatique' in Scriptorium 4 (I950), pp. I77I93. Furthermore, he collaborated with H. Vanderhoven and P. B. Corbett to prepare a diplomatic edition of Regula magistri, a sixth century monastic manual. Their edition was hailed as an authoritative exemplar of diplomatic editions. See: H. Vanderhoven, F. Masai and P. B. Corbett, Regula magistri: La Règle du maître. Edition diplomatique des manuscrits latins 12205 et 12634 de Paris (Brussels, I953), 4 pls.

${ }^{72} \mathrm{On}$ the methods and challenges of editing unique manuscripts, see: Frantz Bäuml, 'Some Aspects of Editing the Unique Manuscript: A Criticism of Method,' Orbis Litterarum I6.I-2 (February I96I), pp. 27-33; Edmond Faral, 'À propos de l'Édition des Textes Anciens. Le Cas du Manuscrit Unique,' Recueil de Travaux offert à M. Clovis Brunel (Paris, I955), pp. 409-42I.

${ }^{73}$ For some more elaborate discussions of how critical textual editing and textual criticism evolved in Indology and Sanskrit Studies, see: Jürgen Hanneder, To Edit or Not to Edit: On Textual Criticism of Sanskrit Works (Pune, 2017); Michael Witzel, 'Textual Critcism in Indology and in European Philology during the $19^{\text {th }}$ and $2 \mathrm{O}^{\text {th }}$ centuries,' Electronic Journal of Vedic Studies 2 I.3 (20I4), pp. 9-9I; Jürgen Hanneder and Philipp A. Maas, Text Genealogy, Textual Criticism and Editorial Technique (Vienna, 2009-IO); Philipp A. Maas, 'A Phylogenetic Approach to the Transmission of the Tibetan Tanjur- the Akșayamatinirdésa Revisited,' in Bauddhasāhityastabakāvatī, (eds.) Dragomir Dimitrov, Michael Hahn and Ronald Steiner (Marburg, 2008), pp. 229-243; S. M. Katre, Introduction to Indian Textual Criticism (Bombay, I94I).

${ }^{74}$ When Embar Krishnamacharya published his edition of RVM in I9I7, he too relied on a "unique" manuscript of the literary work. However, he-unlike Chaudhuri-refrained from calling it a "critical" edition.

${ }^{75}$ Jatindra Bimal Chaudhuri, Works of Rudra of the Court of Pratapsimha (Calcutta, I959), p. 22.
} 
apparatus. $^{76}$ In the light of these observations, one wonders what drove Chaudhuri to conclude that the manuscripts he eventually included in his critical apparatus were unique and contained one independent work each.

When Chaudhuri embarked on the project of reproducing the content of the Bühler manuscripts, there was no consensus among scholars about how many of Rudra's works were contained in the collection. There were disagreements about the proper titles of his panegyrics, and scholars were still divided on who exactly was being eulogised in these poems. No testimonia or intertextual reference shed any light on the length, scope and content of his panegyric poems. To justify their views about these poems, Dalal had cited four verses from the Nagpur manuscript (then the Nashik manuscript) in I9I7; Sharma quoted a few isolated extracts from the Bühler collection in I940; and Karambelkar reproduced some sections of the Nagpur manuscript in 1952.

To complicate the issue further, all scholars concurred that the extant manuscripts of Rudra were "fragmentary" and "corrupt". When Chaudhuri revisited the Bühler collection, he too struggled to make sense of its content. He described Bühler 7ob as a "hopeless medley of confusion", and he conceded that he "was not sure about the real beginning of the works in question". Yet he concluded that "the three works Nawab-Khān-Khānān-carita, Dāna-Sāha-carita and Kirti-samullasa have all been mixed up" in the manuscript. As if it were a resolution to the problem at hand, he declared that "all the contents had to be scrutinised and rearranged in accordance with the subject-matter under discussion". However, insofar as the "subject-matter" of each panegyric was still unknown, Chaudhuri had no firm ground to assume that the Bühler collection contained only three independent works. Nevertheless, he proceeded with his project of critically editing the manuscripts. To affirm the presence of three unique manuscripts in the Bühler collection, he, in fact, engendered three unique works of Rudra. His edition, consequently, was a gross misrepresentation of the codicological features and textual content of the Bühler collection.

Although the Bühler collection at the India Office Library is comprised of three distinct manuscripts (Bühler 70a, 7ob, 70c), they were originally part of the same manuscript. When one combines them, they form a composite whole of 2 I folios. Since all the folios are numbered, they can be readily rearranged in their proper sequence. When properly assembled, they form a complete and unbroken volume of manuscripts. This regular ordering and numbering of the folios was noticed by the curators of the India Office Library who arranged them in order and bound them together with two other manuscripts-Krī nanda and Probodhacandrodaya of Kṛ̣namiśra-sometime before 30 October 1908. Since none of the folios are missing, there is no unintended rupture in textual flow. That the manuscript was originally conceived to contain 2I folios is further supported by the opening and closing folios of the composite volume. ${ }^{77}$ The scribe indicates clearly where he intended to begin the original volume and where he wished to end it.

Of the three Bühler manuscripts, it is the first folio of Bühler 7oa that displays distinct traits of a manuscript's beginning (Fig I). Its opening phrase pays homage to Lord Ganeśa: "Reverence for Lord Ganeśa!" (śri ganeśâya namah). This is a typical invocation that scribes use at the

\footnotetext{
${ }^{76}$ Ibid., p. 7 .

${ }^{77}$ For previous scholarship on composite manuscripts, see footnote 7 .
} 


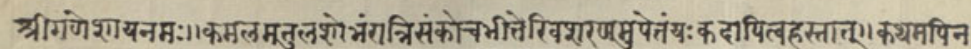

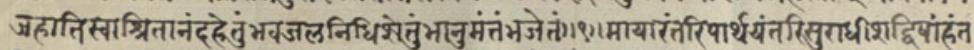

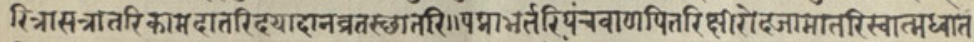

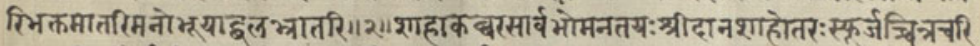

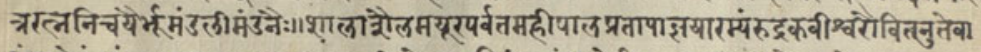

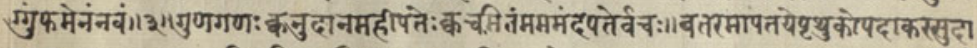

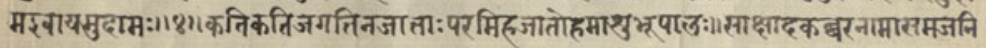

Fig. I. Folio Ib, Bühler 70a (Ms. 7089): The first folio of the composite volume.

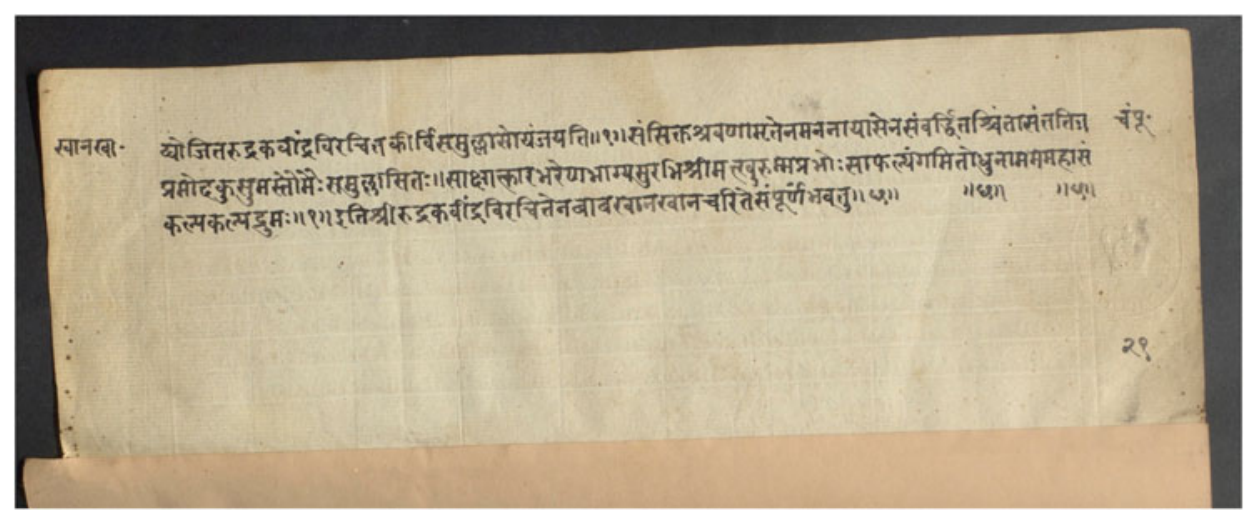

Fig. 2. Folio 2rb, Bühler 70c (Ms. 7303): The last folio of the composite volume.

beginning of a manuscript. This salutation is followed by a verse (śloka) which the scribe identifies as the first verse of the poetic anthology. Since most verses and folios are numbered in these Bühler manuscripts, readers can recognise the appropriate verse sequence and original structure of the literary compositions in the anthology. Thus, the opening invocation and the verse numbering show that the first folio of Bühler $70 a$ was originally conceived as the first folio of the composite volume.

The last folio of Bühler $70 \mathrm{c}$ constitutes the final folio of the composite volume (Fig. 2). This is where the scribe finished copying the content of his exemplar. This is not an abrupt ending for the manuscript. There is no evidence to suggest that the scribe was ideologically motivated, financially deprived or even poetically inspired to tamper with the exemplar's content or to terminate his copying abruptly. No incongruous physical marks, textual elements or circumstantial evidence exist to indicate that the scribe had abruptly stopped copying his exemplar. The scribe certainly did not quit copying the exemplar because he ran out of paper or ink. Both the accumulation of ink at the curved ligatures of devanāgari letters and the bold shade of the straight strokes in the last folio clearly indicate that the scribe's stylus had sufficient ink until the end of the manuscript. Neither was there a shortage of paper. The text of the last folio of Bühler $70 \mathrm{c}$ extends until the third row which is less than half 
of the breadth of the folio. Had his exemplar contained more text, the scribe would have copied them at least until the end of this folio. The leftover space in the folio can fit about half a dozen ślokas in, say, anuștubh meter. However, irrespective of the availability of material and financial resources, a scribe is obliged to stop as soon as he finishes copying all the text of his exemplar. Indeed, the final sentence of the folio acknowledges the ending of a work by Rudra.

iti šrīrudrakavīndra viracite nabābakhānakhāna carite sampūrnạn bhavatu ||

Let it be the ending of Nabābakhānakhānacarita composed by the great poet Rudra.

Additionally, the scribe has the idiosyncratic habit of marking the end of textual segments. ${ }^{78}$ If the content of a textual segment ends in a specific row, he fills some of the remaining space of that row with an alternate sequence of double vertical bars $(||)$ and a compound-letter that-although it resembles the letter "cha" or the number six in modern devanāgari or kaithi scripts - denotes the Sanskrit word "srî" in this manuscript. This stylistic element is noticeable in the third row of folio 4a (Bühler 70a), the fifth row of I za (Bühler 7ob), the fifth row of I7a (Bühler 70a), the fourth row of I 8b (Bühler 70c) and finally in the third row of $2 \mathrm{rb}$ (Bühler 7oc). Since it appears for the last time on the last folio of Bühler 7oc (folio $2 \mathrm{Ib}$ ), one may fairly conclude that it signals the end of the composite manuscript.

The manuscript's composite nature is reaffirmed by the fact that all three underlying manuscripts were copied by the same scribe. The idiosyncratic use of an alternating sequence of double bars $(||)$ and śr $\bar{r}$ to signal the ending of textual segments are noticeable in all three Bühler manuscripts. After this distinct closing sequence, he sometimes remembers Lord Rāma (śn rāma), for example, on folios I $3 \mathrm{a}$ and I 5 b. The scribe has a characteristic style of writing some of the conjunct consonants, which is apparent in all three manuscripts. For instance, his "stha" (as in "sthatari" or "sthitam") appears like the "scha" of contemporary devanāgari script, and his "ṣna" (as in "viṣnu") appears identical to the conjunct consonant "lla" (as in "ullāsa") in current scribal practices. Moreover, the same kind of scribal, orthographic and grammatical errors are evident in all three manuscripts. He is fairly consistent in leaving out a consonant before or after the vowel signs of both the short " $i$ " and long "ঙ" and he tends to repeat the same set of misspellings (for instance, "māhârāja" for "mahäraja"). On the other hand, he maintains a certain degree of stylistic uniformity in the organisation of the text in all three manuscripts. Except for three folios ( $1 \mathrm{~b}, \mathrm{I} 5 \mathrm{~b}$ and $2 \mathrm{Ib}$ ), each of the remaining $\mathrm{I} 8$ folios in the three manuscripts contain eight rows of text. The margin area of all four sides in each of the three manuscripts is almost equal. The reverse side of each folio carries the phrase "khānkhāa" "79 at the top of the left margin, just before the beginning of the first row, and it bears the folio number at the bottom right margin, just after the end of the last row. Both the stylistic uniformity of the manuscripts and the peculiar features of the handwriting indicate that all three manuscripts of the Bühler collection were copied by the same scribe.

Among the surviving manuscripts of Rudra's work, the Bühler collection stands out for the exemplary craft and writing style of the scribe. In contrast to the scribe of the Baroda

\footnotetext{
${ }^{78} \mathrm{~A}$ textual segment may consist of a section of a chapter, a chapter of a book or a complete literary work.

${ }^{79}$ The hyphen is included in the phrase that appears in the manuscript.
} 
Fig. 3. Folio I Ib, Bühler 7ob (Ms. 7304).

manuscript, the Bühler collection's scribe exhibits remarkable steadiness and poise in copying his exemplar. His letters are usually well-formed and complete, and his sentences are properly punctuated in most folios. Both the curved and the straight strokes of his letters reveal that he exercised considerable control on his stylus as he copied the exemplar of the composite volume. There is no definitive evidence to prove that the scribe was tired, inattentive and/or negligent in copying the manuscripts. Among the $2 \mathrm{I}$ folios of the three manuscripts, there is just one instance where one may argue that the scribe was physically tired or distracted, which may have affected his handwriting and copying (Fig. 3). This moment appears precisely in the middle of the composite volume. In folio I Ib, his letters grow a bit larger in the third row and remain enlarged until the end of the folio. The letters regain their original size and form by the beginning of the next folio. If, indeed, the scribe was exhausted or distracted here, ${ }^{80}$ his physical strain or distraction was not intense enough to deform-beyond recognition-his characteristic writing style. While the letters are somewhat enlarged, they do not betray any sign of stylistic disorientation or cognitive dissonance. They are far from becoming illegible. In fact, the larger size of folio I Ib is almost identical to the first folio of Bühler 70a, where the scribe deliberately introduces a larger font.

Based on the remarkable regularity, poise and consistency in handwriting, it is apparent that the scribe was very attentive and careful while copying the exemplar. In spite of his focus and skill, the Bühler collection abounds in unusual grammatical and orthographic forms. Why did the scribe - and/or his reader ${ }^{81}$ - refrain from editing the text? ${ }^{82}$ Even if they were not well versed in Sanskrit literature, they could still have rectified some of the basic spelling and grammatical errors. That the scribe consistently reproduces the same kind of errors throughout the manuscript shows that he-and/or his reader-was solely

\footnotetext{
${ }^{80}$ The shift in calligraphic style is not always caused by the scribe's fatigue. It is possible that a new scribe has begun copying the manuscript. This, however, is not the case with the Bühler manuscripts.

${ }^{81}$ Sometimes scribes employed readers to dictate the text of exemplars. It is unclear whether the scribe of the three Bühler manuscripts employed a reader.

${ }^{82}$ Scribes regularly performed editorial roles while copying manuscripts. For a discussion of the relationship between premodern authors and editors, see: Jürgen Hanneder, "Pre-modern Sanskrit Authors, Editors and Readers," in Indic Manuscript Cultures through the Ages: Material, Textual, and Historical Investigations, edited by Vincenzo Vergiani, Daniele Cuneo and Camillo Alessio Formigatti (De Gruyter, 20I7), pp. 223-238.
} 
interested in copying the exemplar; they were not concerned about the grammar and meaning of the content. Given their singular focus on faithfully reproducing the text of the exemplar, the scribe has in effect produced a reliable copy of the exemplar.

Although the scribe had performed his task skilfully, he was still held responsible for the "fragementary" and "corrupt" condition of Rudra's compositions. Both traditional and modern scholars are prone to privileging Brahmin poets at the expense of scribes. ${ }^{83}$ This tendency of lauding Brahmin poets and blaming scribes is all the more conspicuous whenever scholars encounter atypical manuscripts. When confronted with various grammatical and literary irregularities in the Bühler manuscripts, scholars - instead of questioning the literary credentials of the poet - held the scribe responsible for the flaws and inadequacies in Rudra's poetry. Even though much of his panegyrics had not yet been critically reconstructed, most scholars applauded the Brahmin poet and his modest literary output. Chaudhuri unhesitatingly remarked, "Rudra was a great Kavi." 84

In the end, scholars did not pay attention to the nature and scope of scribal agency in determining the content and form of the Bühler manuscripts. Furthermore, they failed to notice that these three manuscripts were part of a composite volume, whose codicological attributes differed substantially from those of unique manuscripts.

\section{A Poetic Anthology in the Making}

A literary work does not always begin on the very first folio of a manuscript. Nor does it always end on the last folio. This is usually the case when a manuscript contains an anthology of literary compositions and not just one work. Some of the codicological features of an anthological manuscript are, therefore, markedly different from that of a unique one. For instance, the colophon of a unique manuscript usually appears in the last folio ${ }^{85}$ and may adequately identify the work's title, authorship, patronage and the locus (time and place) of composition or copying. ${ }^{86}$ When a manuscript contains multiple works, the colophon that appears in the last folio may not adequately document the identity of all the works contained in the anthology. In such a case, a codicologist examines all the manuscript's folios to identify the respective ending of each work. The codicological differences between anthological and unique manuscripts were not apparent to scholars perusing the Bühler collection.

When Aufrecht came across the Bühler collection in I89I, he read one of its manuscripts as if it were a unique copy of a poetic work of Rudra. Hence, the colophon on the last folio

\footnotetext{
${ }^{83}$ An anonymous śloka that appears in the colophons of several South Asian manuscripts reads: jalādrakṣet tailādrakșed rakṣecchithilabandhanāt| mūrkhahaste na mām dadyāditi vadati pustakam || "Protect me from water, protect me from oil, protect me from stiff knot, don't put me in a stupid-hand," thus speaks a book.
}

Although "stupid-hand" (murkha-hasta) can refer to anyone who lays hand on the manuscripts and manhandles the book, its association with the hands of a scribe is somewhat obvious since manuscripts were primarily handled by Brahmins and scribes in early modern times.

${ }^{84}$ Jatindra Bimal Chaudhuri, Works of Rudra of the Court of Pratapsimha (Calcutta, I959), p. 24.

${ }^{85} \mathrm{~A}$ unique manuscript may contain multiple colophons, in which case one peruses all colophons in the manuscript to determine its identity.

${ }^{86}$ This is not an exhaustive list of details that are usually found in a colophon. These details vary from one manuscript to other. 
of Bühler 7oa became the primary evidence for his identification of Rudra's work. This colophon reads:

śrīman bäbakhānacarite prathama ulläsă $\|1\|^{87}$

[This is] the first chapter of The Life of Honorable Bāba Khāna.

For Aufrecht, the presence of this colophon in a unique copy of a manuscript proved that Rudra had composed only Bābakhānacarita (The Life of Honorable Bāba Khāna). ${ }^{88}$

When Chaudhuri revisited the same folio, he too believed he was reading a unique manuscript of a poetic work, and not an anthology of multiple compositions. Unlike Aufrecht, however, he had gathered from the remaining folios of the manuscript that the literary work in question was Navāvakhānakhānānacarita-not Bābakhānacartitra-of Rudra. Consequently, he modified the text of the colophon in his critical edition as follows:

śrīman navāvakhāna[khānāna]carite prathama ullāsah || 1 ||

[This is] the first chapter of The Life of Honorable Navāvā Khāna Khānāna.

While Chaudhuri placed the phrase "khānāna" within square brackets to denote his editorial emendation, he does not acknowledge his inclusion of "na" after śrimman and his replacement of "ba" with "va". In this specific case, however, his editorial emendations - with or without his acknowledgement - were justified because both "nabāba" and "khānakhānāna" recurs several times in the text preceding the colophon. But he was hardly wary of misusing his editorial prerogatives when he recast the composite volume of a poetic anthology as three independent panegyric poems. In doing so, he radically altered the formal, structural and literary makeup of the Bühler manuscripts.

Two invocatory ślokas - one praising the divine Sun and the other venerating Krṣnamake up the prologue of the $N K C$ in his diplomatic edition. No invocation is found at the beginning of the NKC in the Bühler manuscripts. The Brahmin poet does not seek blessings from any Hindu god before he begins eulogising the glory of a Muslim hero with the title of "Khān Khānān". However, since a proper campū kāvya conventionally opens with an invocation, Chaudhuri decided to commence his critical edition of the NKC with a pair of invocatory verses that originally appear at the beginning of the $D C$ - not the $N K C$ - in the Bühler manuscripts. This displacement of both verses not only disregards the structural arrangement of the camp $\bar{u}$ kâayas in the Bühler manuscripts, it also misrepresents and misconstrues the primary role of these verses in the poetic anthology. This invocation was intended to christen the commencement of the poetic anthology as a whole and not any specific work within it.

Although Chaudhuri had correctly identified the folio where the NKC begins, he still misrepresented the opening section of the panegyric in his diplomatic edition. Apart from supplying an absent invocation, he recast the first paragraph of the panegyric in a diffused

\footnotetext{
${ }^{87}$ The scribe has placed a halanta below the letter "na" at the end of śriman. Contrary to the established orthographic custom of combining conjunct consonants, he does not attach the half of "na" with the following "ba". Both śriman and halanta appear several times in the manuscript. On comparing them, it seems evident that the scribe intentionally placed halanta below the "na" instead of combining it with "ba."

${ }^{88}$ Theodor Aufrecht, Catalogus Catalogorum. An Alphabetical Register of Sanskrit Works and Authors (Leipzig, I 89I), p. 528 .
} 
form to highlight both the "abrupt" beginning of the literary work and the "fragmentary" nature of its manuscript. This is how he recreated the inaugural section of the NKC in his edition:

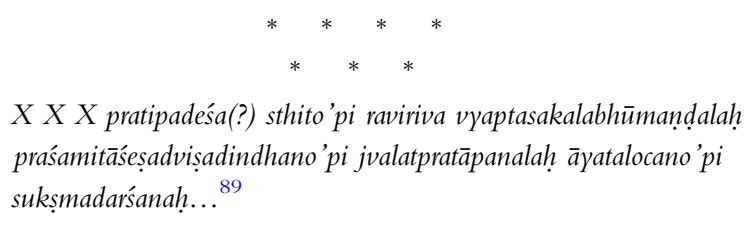

Chaudhuri introduced two rows of asterisks between the invocation and the first paragraph of the NKC in order to indicate some sort of rupture in the work. This editorial decision misleads readers into believing that a textual segment is missing here, that is, either a folio has been lost, or a part of this folio was destroyed by natural or accidental causes. The repetition of the cross mark $(\mathrm{X})$ three times further reaffirms the notion in readers' minds that the opening phrases of the first sentence of the NKC are irrecoverable from the manuscript. To accentuate the "corrupt" textual content of the manuscript, the editor removed all end punctuation - that is, double bar $(||)$ - from the first paragraph. Thus, one long, incomplete, fractured and unpunctuated sentence opens his edition of one of the most notable campu kāvyas of Rudra. In contrast to what Chaudhuri provides in his edition, the Bühler manuscripts offer a complete and unruptured paragraph at the start of the NKC.

palāyitamahājenasabalašāhanirmūlitapratipadeśa sthito 'pi raviriva vyaptasakalabhūmañdalah

| praśamitāseșadvișadindhano'pi jvalatpratāpanalah || āyatalocano'pi sukṣmadarśanah ||

Chaudhuri tampered with the ending of the NKC as well. The final chapter in his diplomatic edition consists of six ślokas, but the same section in the Bühler manuscript (folio I 3 b) has only five. After the fifth śloka, the scribe deploys his characteristic closing sequence of a double bar $(||)$ and śrin, followed by his personal refrain, "śrī rāma". Thus, the scribe clearly indicates that the poet intended the prior section to end right after the fifth sloka. Contrary to what is preserved in the manuscript, Chaudhuri turned the first sloka of the next section into the final śloka of the preceding section of the NKC. Moreover, the last chapter of his edition does not end with a colophon but rather with a row of five asterisks that Chaudhuri used to denote the ending of the NKC. By violating the structure and composition of the manuscript, Chaudhuri not only reinforced the notion that the Bühler manuscripts were corrupt and incomplete, he simultaneously reaffirmed the presence of a unique manuscript of the $N K C$ that was made up of four chapters.

What Chaudhuri did not explain in his diplomatic edition is why his fourth chapter (caturtha ullassa) should be viewed as an integral part of the NKC. How did he conclude that Rudra intended to compose four chapters for the $N K C$ when none of the eight colophons in the three Bühler manuscripts attest to the presence of a fourth chapter in praise of Khān Khānān? If the scribe had erroneously left out a colophon from the exemplar, how did the editor determine that a particular textual segment relates to the NKC and not to any other work in the anthology? Without a colophon, one may never know whether the

\footnotetext{
${ }^{89}$ Jatindra Bimal Chaudhuri, Works of Rudra of the Court of Pratapsimha (Calcutta, I959), p. I.
} 
"fourth chapter" was an integral part of the poet's panegyric; or whether it was appended later at the behest of new audiences; or whether it was the opening of a new panegyric composition; or whether it was a personal postscript that the poet noted down once he delivered his panegyric.

Without a colophon, a chapter remains incomplete. A colophon is where an author or scribe formally announces that a specific chapter of a literary work has come to an end. Apart from the colophon, the last verses of a chapter may reveal the identity of both the work to which the chapter belongs and its author. Some poets may describe their personal and professional identity in their closing remarks. Sometimes they expound on their poetic motivations and literary influences, and they may even document the historical circumstances surrounding the production of their works. For instance, they may record the date and place of composition, the sources of patronage, the prevailing political conditions and the religious and cultural backgrounds of the literary community. This conventional way to conclude a work is noticeable in the compositions of Rudra. The last six ślokas of the RVM (20.95 to 20.IOI) and the last śloka of the DC show that he uses the ending of his literary works to explain why, how and when he completed his composition. The closing verses of the "fourth chapter", however, exhibit no such trait of being a formal ending for the NKC. On the contrary, the third chapter (trtitya ulläsa) retains all attributes of a proper ending - similar to the closing verses of both the RVM and the DC. It reads:

\author{
šäke kṣmāgnitithau saumye vaišākhe śuklapakṣatau | \\ caritraì khā̄nakhānasya varṇitaì rudrasūriṇa || \\ In the cool vaišäkha month (April-May) \\ and śukla-pakșa (brighter lunar half of the astrological month) of \\ the Śaka year of the I53 I (I609-IO CE), \\ The Life of Khān Khānāna has been portrayed by Rudra Sūri. ${ }^{90}$
}

When Karambelkar read the final śloka of the third chapter in the Nagpur manuscript, he justifiably concluded that it signalled the final chapter of the NKC. Hence, the last sloka of the third chapter was the final sloka of the work, and the colophon of the third chapter was the final colophon of the NKC. By the same logic, when describing the textual segment that appeared after the third colophon in the manuscript and that continued describing the life and deeds of Khān Khānān, he called it a "post-colophon". This textual segment was not a "fourth chapter" in Karambelkar's assessment.

Although the term post-colophon has been in circulation for more than a century now, its history, standard usage and implications remain unclear and confused in Indological studies. Baffled by its irregular usages, Dominik Wujastyk posted a question on his Cikitsā weblog on 26 January 20I2: "Am I right that nobody outside Indological circles (and those influenced by Indologists in the last few decades) uses the term 'post-colophon'?" He was confounded by the nonstandard usage of this term in the works of David Pingree, C. Tripathi and Pratapditya Pal. ${ }^{91}$ He believed that it was Pingree who "introduced the term 'post-colophon'

\footnotetext{
${ }^{90}$ Here kṣema refers to I, agni to 3 , and tithi to I 5 . Thus, the expression kṣemāgnitithau denoted the year I 53 I of the Śaka calendar.

${ }^{91} \mathrm{D}$. Pingree, A descriptive catalogue of the Sanskrit and other Indian manuscripts of the Chandra Shum Shere collection in the Bodleian Library (general editor Jonathan Katz). Pt. 1. Jyotihśästra (Oxford, I984); Pratapaditya Pal, The Arts of
} 
into Indian manuscripts when he wrote his catalog of the Bodleian Chandra Shum Shere Jyotișa collection" in $1984 .{ }^{92}$ Given the discrepancy in its usage, he has avoided the term in his cataloguing projects. ${ }^{93}$ However, it was not Pingree who introduced the idea of postcolophon into the study of Indic manuscripts. The term was already in use in the first half of the twentieth century.

Sometime before the I950s, the Ministry of Scientific Research and Cultural Affairs, Government of India, had issued a national directive to all state-owned archives in India that both the colophon and post-colophon of a manuscript should be recorded in their descriptive catalogues. ${ }^{94}$ Consequently, when Jinavijaya Muni published the catalogue of Sanskrit and Prakrit manuscripts that the Rajasthan Oriental Research Institute had collected between I95 I and I956, he organised the codicological details of the manuscripts according to the official directive. Indeed, his catalogue was the first to duly obey the norms established by the state. It is evident from his codicological study of 3,I75 manuscripts that the term postcolophon was explicitly intended to identify the scribe- not the poet or author-of a manuscript. Compared to their Islamic counterparts, Hindu scribes were less likely to reveal their identity once they finished copying a manuscript. Still, it is not uncommon to come across Sanskrit manuscripts where the scribes reveal their identities in what Jinavijaya Muni had identified as the post-colophon of the manuscript.

Both Karambelkar and Jinavijaya Muni were cataloguing manuscripts around same time, albeit in different states of India. They differed in their interpretation and usage of the term post-colophon. For Karambelkar, the post-colophon did not represent the identity and intentions of a scribe; it still was a poet's contribution to the textual content of a manuscript. In his view, the post-colophon is a textual segment that appears after the final colophon of a work in the manuscript. Insofar as a post-colophon is composed after the completion of a work, it is not an integral part of that work. It may or may not have any relation to the preceding work in the manuscript.

By treating post-colophon as an external appendage to a literary work, Karambelkar concluded that "the entire work [of NKC] is a fine specimen of Sanskrit ornate prose and poetry but it is curiously silent about the historical aspect of the hero under description". "At the same time, he was glad that Rudra had made his poetic and political intentions explicit in the post-colophon section of the manuscript, which allowed modern critics to make sense of the "curiously silent" nature of the NKC or, as he puts it, to catch "a glimpse of the scene behind the curtain" of the political stage. Unlike Jinavijaya Muni, Karambelkar did not believe that the post-colophon represented the views and identity of the scribe. For Karambelkar, the post-colophon was merely a means to uncover "the secret lying behind this apparently

Nepal. Part II. Painting with 220 plates (Leiden and Köln, I978); Chandrabhāl Tripāṭī, Catalogue of the Jaina Manuscripts at Strasbourg. Indologica Berolinensis. Herausgegeben Vom Museum Für Indische Kunst Berlin, Staatliche Museen Preussischer Kulturbesitz Und Vom Institut Für Indische Philologie Und Kunfstgeschichte Der Freien Universität Berlin, Band 4 (Leiden, I975).

${ }^{92}$ https://cikitsa.blogspot.com/2012/oI/colophons-names-of-text-portions-in.html (as accessed on I9 December 20I9).

${ }^{93}$ Dominik Wujastyk, email message to the author, 22 April 2016.

${ }^{94}$ Jinavijaya Muni, A Catalogue of Sanskrit and Prakrit Manuscripts in the Rajasthan Oriental Institute (Jodhpur Collection), Part I, Rajasthan Puratan Granthamala No. 7I (Jodhpur, I963), p. 3.

${ }^{95}$ V. W. Karambelkar, "Nabābakhānakhānānacaritam," The Indian Historical Quarterly, (ed.) Narendranath Law, Xxviii (I952), p. 244. 
unhistorical panegyric". 96 So, "by way of conclusion", Karambelkar argued that "Rudra's NKC was a mere covering, a pretext to hide the petition of succor" that had been "appended to it in the five verses to the post colophon". 97

The notion that the last five verses making up the post-colophon should be treated as an external appendage and not an integral constituent of the work was not acceptable to Audrey Truschke who dismisses Karambelkar's reading as "problematic on several levels". ${ }^{88}$ She, however, elucidates only two problematic facets of his reading. First, she claims that his reading "dismisses Rahīm's fame" as "an aficionado of Indian languages" and, second, it is unable to "account for several verses in the poem that hint at Pratap Shāh's intentions". ${ }^{99}$ Her criticism is not a fair reassessment of the codicological and textual issues Karambelkar was grappling with in his reading of the Nagpur manuscripts. At the end of the same paragraph in which Truschke first criticises Karambelkar's reading as "problematic", she concedes that the "subtle references" in the three chapters of the NKC "hardly rival" the "closing petition"- that is, the post-colophon in Karambelkar's reading-of Rudra. At no point in her analysis did Truschke address the key codicological issue underlying the reconstruction and interpretation of the NKC: why should one consider a textual segment appearing after the colophon of the third chapter to be an integral part of a work that is not alluded to in the fourth colophon of an anthological manuscript? Was it an afterthought by the poet, or a postscript for his performers, or an emendation by his scribes, or a commentary by an anachronistic editor?

The idea that Karambelkar's post-colophon was the same textual and literary phenomenon as Chaudhuri's "fourth chapter" was a convenient assumption for Truschke's argument. Without the "fourth chapter" of Chaudhuri's edition, the meaning and interpretation of the NKC changes radically. The collocation "Navāb Khān Khānān" is merely an honorific that may be bestowed upon anyone in a eulogistic context. That it referred specifically to 'Abd al-Rahīm in the NKC is conclusively established only in the fourth section where his sons-Mīrzā İraj and Dārāb (they are respectively called "Mīrjìyalī”" and "Dārāb" in the NKC) - are specifically named. Had Chaudhuri not included the "fourth chapter" in the main body of the NKC, the identity of the person eulogised in the panegyric would remain ambiguous. By presenting the post-colophon as the fourth chapter, Chaudhuri gave himself a definitive ground to argue that the $N K C$ was a eulogy of 'Abd al-Rahīm (and not of Jahāngīr or any other Mughal elite), and he simultaneously enhanced the historical and political value of the NKC as a campū kāvya. The fourth section provides significant historical and political details about the role of Khān Khānān in the contemporary politics of the Mughal Empire and the condition of subservient rulers like Pratāp Shāh. Aided by the "fourth chapter" the NKC becomes an instrument of political diplomacy insofar as it expresses Pratap Shah's direct appeal to Rahīm, requesting the latter to secure his kingdom from the threat posed by the Mughal army. Based on the "fourth chapter", Truschke was able to conclude, "In the panegyric's fourth and final chapter, comprised

${ }^{96}$ Ibid., p. 245

${ }^{97}$ Ibid., p. 245 .

${ }^{98}$ Audrey Truschke, 'Cosmopolitan Encounters: Sanskrit and Persian at the Mughal Court,' (PhD dissertation, Columbia University, 2012), p. 78.

${ }^{99}$ Ibid., p. 78 . 
of five verses, Rudra speaks more directly to the ability of Sanskrit poetics to participate in the Mughal politics". ${ }^{100}$

When Pratāp Kumār Miśra noticed that the "fourth chapter" in Chaudhuri's edition was missing a colophon, he resolved the problem by composing two novel colophons: one for the "fourth chapter" and another for the final ending of the NKC.

$$
\begin{aligned}
& \text { iti śrìrudrakaviviracite navābakhānakhānānacarite caturtha ullāsah || } \\
& \text { iti navābakhānakhānānacaritābhidham campūkāvyam sampāptimagāt || }
\end{aligned}
$$

This is the fourth ullāsa in the Life of Navāba Khāna Khānāna composed by Śrī Rudra.

Thus, the campū kāvrya by the name of the Life of Navāba Khāna Khānāna has reached its end.

By inventing these colophons in his Hindi edition, Miśra obviously disregarded both the codicological and literary content of the Bühler manuscripts. The fact that editors could supply a colophon as and when they wished shows how the codicological significance of colophons in scribal cultures was readily undermined by modern editorial practices at large.

Miśra's creative intervention can still be appreciated as an attempt to fill a major gap in Chaudhuri's reconstruction of the camp $\bar{u}$ kâvyas of Rudra. But howsoever liberally one may define the scope of editorial interventions in the reconstruction of an incomplete literary work, the editor must remain sensitive to the literary, stylistic and formal features of the work that actually appears in the manuscript. Unfortunately, while composing his colophons, Miśra strayed from the language and grammar of Rudra's colophons. There are eight colophons in the three Bühler manuscripts. In none of these colophons does the poet resort to an aorist construction (agat t) for announcing the end of a chapter. Nor does he ever use "samāpti" — a feminine krdanta (ktin-pratyayānta) form-to denote the ending of a textual segment. Apart from the Bühler manuscripts, the Baroda manuscript of the $R V M$ consists of twenty colophons, and Rudra does not use either the aorist conjugation of "agāt" or the feminine declension of "samāpti" to mark the ending of a chapter. Granted the creative imagination of poets is not confined to what they have cultivated in their past writings, so it is possible that Rudra could have used both forms in one of his later colophons. Critical editors and literary critics, however, are usually guided by what poets have left behind in their writings, not by what they could have possibly written in the future. Driven by the impulse to create a unique and complete edition of a literary work, Miśra, like his predecessors, neglected the study of colophons.

\section{A Draft Copy of an Anthology}

The eight colophons that were eventually inscribed in the Bühler manuscripts reveal some crucial elements of Rudra's creative imagination and poetic intention. In addition, they resolve some of the key codicological and textual issues that have adversely affected the critical interpretation of his literary oeuvre. The eight colophons in the composite volume of the Bühler collection appear on folios $4 \mathrm{a}, 6 \mathrm{a}, \mathrm{Iob}, \mathrm{I} 2 \mathrm{~b}, \mathrm{I} 5 \mathrm{~b}, \mathrm{I} 7 \mathrm{a}, \mathrm{I} 8 \mathrm{a}$ and $2 \mathrm{rb}$.

\footnotetext{
${ }^{100}$ Audrey Truschke, 'Regional Perceptions: Writing to the Mughal Court in Sanskrit,' in Cosmopolitismes en Asie du Sud: Sources, itinéraires, langues (XVI - XVIII ${ }^{e}$ siècle), edited by Corinne Lefevre, Ines G. Županov and Jorge Flores (Paris, 20I5), p. 26I.
} 


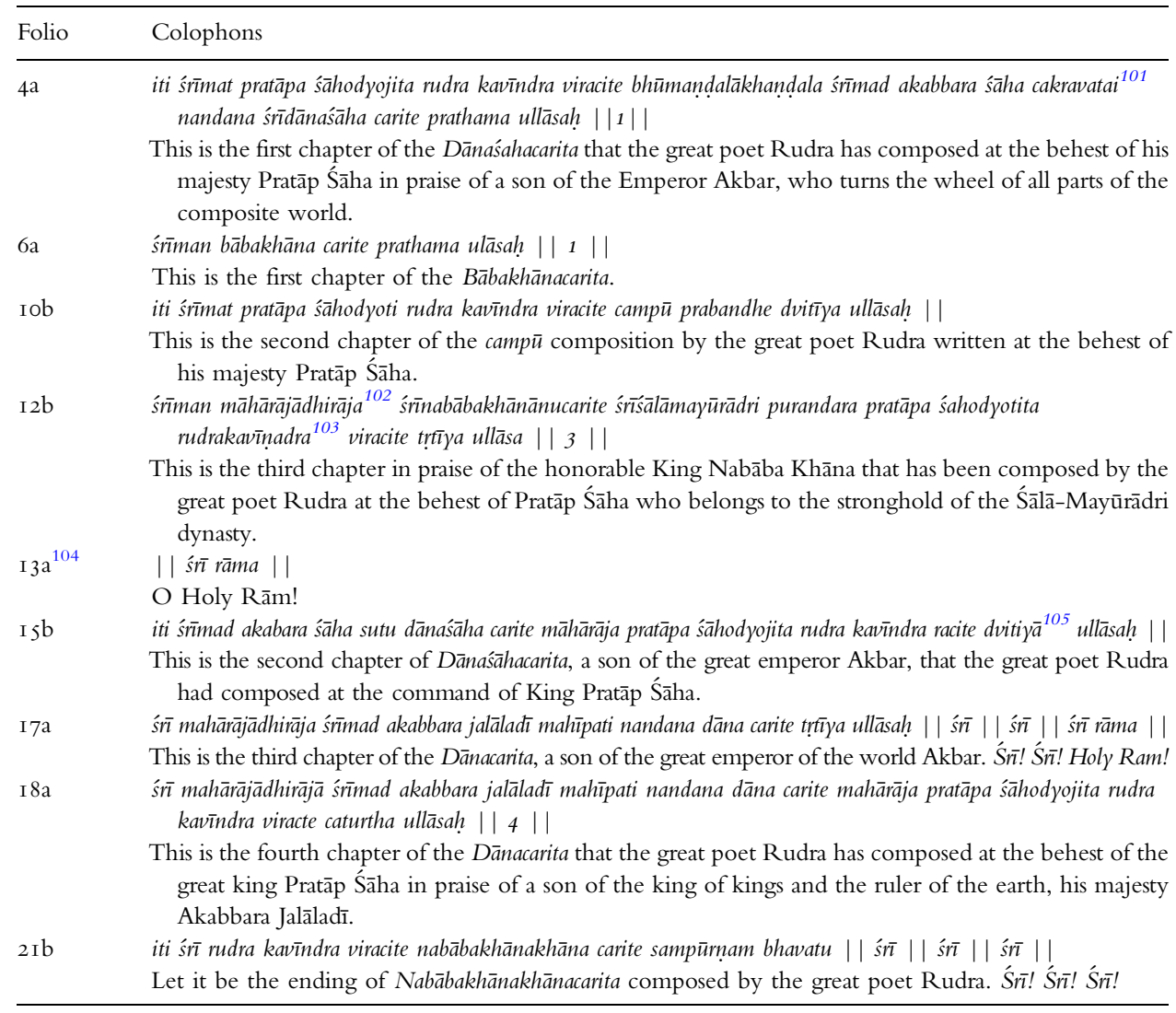

None of the colophons indicate the presence of a "fourth chapter" (caturtha ullāsa) in the NKC. Nor are they ambiguous in acknowledging the work to which they belong. The five slokas that comprised Chaudhuri's "fourth chapter" and Karambelkar's post-colophon appear in two folios: $\mathrm{I} 2 \mathrm{~b}$ and I $3 \mathrm{a}$. The fifth sloka is followed by the scribal refrain

\footnotetext{
${ }^{101}$ The scribe has copied "cakravatai" [चक्रवतइ] several times in the manuscript. In the final syllable "tai" of "cakravatai," he writes "ta" and "i" separately. He does not use the mātrā (diacritic) of "i" with "ta". His style of writing "i" the end of "cakravartai" is different from the "i" that appears at the beginning of words like "iti," "ittha," or "indra". He maintains these orthographic nuances throughout the manuscript. His preference for regional orthographic practices should not be misconstrued as evidence of "scribal error". One must also note that since the scribe repeatedly uses "cakravatai" instead of "cakravartī", the nominative and singular declension of "cakravartin" in masculine gender, it shows that the poet preferred the Prākrit form of "cakravarti".

${ }^{102}$ The scribe writes "māhāraja" instead of "mahārāja" several times in the manuscript. This dialectal variation may be attributed to the scribe, his reader or his exemplar.

${ }^{103}$ The "ṇa" in "kavinndra" is ungrammatical in Pāṇiṇian Sanskrit as it it does not follow the Pānininian rules prescribed for replacing "na" with "na" (natva vidhāna). However, "na" is frequently replaced by "na" in several Prakrit languages. Since it is the first and last time "ṇa" appears in the place of "na"-diverging from the natva vidhāna of Sanskrit - one cannot discount the possiblity that the reader (dictator) of this folio was different from the reader of the previous folios even though the same scribe continued writing the text.

${ }^{104}$ This is not a colophon. I discuss its implications later in this essay.

${ }^{105}$ The scribe prefers a short vowel instead of the long vowel after "ta" in "dvitiya".
} 
"śn ramma". ${ }^{106}$ While the presence of the refrain indicates that it was a distinct textual segment in the manuscript, the absence of a colophon signals that the textual segment was not a separate chapter. This segment may qualify as a postscript or an afterthought.

One could argue that this segment lacks a colophon because the scribe neglected to copy it from the exemplar. There is no indication of physical laxity (for example, the presence of smudged ink, incongruous letters or irregular tone of strokes) in the scribe's copying of text. From the quality of handwriting and its impeccable stylistic regularity, it is evident that the scribe was consciously terminating a unique section of the manuscript. Given the scribe was reproducing the textual content with fidelity and interest, it is very unlikely that he would have missed a complete colophon from his exemplar.

Yet human errors and slippages do have unusual ways of showing up, so it is possible that the scribe somehow forgot to copy the colophon immediately after the fifth sloka and right before his scribal refrain "śrī rāma". Unless one is overeager to blame the scribe and praise the Brahmin, however, an explanation predicated on the notion of "scribal error" and "fragmentary exemplar" does not go very far. For instance, it does not explain why the poet abandoned both his poetic persona and literary conventions in favour of a direct and realist articulation of his political intentions. After all, realism is not really the forte of conventionally ornate genres and traditional poets. Nor does it imbue those five ślokas with the attributes of a chapter (ullāsa) in the camp $\bar{u}$ genre. This textual segment not only lacks a conventional beginning and a traditional ending, it is ostensibly devoid of a prose section which is the sine qua non for the camp $\bar{u}$ genre. Without a mix of prose and poetry, a work cannot be called campu.

One could argue that the continuity of some specific themes - the sustained praise of Khān Khānān, the reiteration of certain metaphors and imagery, the persistence of particular stylistic attributes - justifies its inclusion in the main body of the NKC. This argument for thematic unity, too, fundamentally misinterprets the codicological and textual attributes of the composite volume. The Bühler manuscripts presents an incomplete and tentative draft copy of Rudra's panegyric works. Throughout the composite volume, the poet improvises, reimagines and experiments with the content of his prospective compositions. That is why he reuses, repurposes and reiterates identical verses, prose passages and rhetorical devices in his panegyric works. For example, the first chapter of the NKC is composed of eight ślokas in honour of Khān Khānān (folios Ib-6a). He reuses all eight ślokas to praise Dāniyāl Mīrza as well. It is no surprise, then, that both sections of the manuscript exhibit thematic likeness in their content and style. This likeness among disparate literary segments of the Bühler manuscripts is incidental to the poet's creative imaginings. This does not characterise a complete and fully formed work.

The tentative nature of the content of the Bühler manuscripts is also conveyed by the irregularity of their colophons. Traditionally, poets and scribes tend to adopt a formulaic sentence for declaring the completion of a specific section of their literary work. Such a sentence retains a regular and congruent syntactic structure in every instance of its

\footnotetext{
${ }^{106}$ If the scribe were copying the text from multiple exemplars, then the scribal refrain may imply that he finished copying one manuscript and commenced with a new exemplar after the refrain. However, there is a dearth of textual evidence to support the presence of multiple exemplars.
} 
occurrence. The symmetry of a formulaic sentence is not apparent, however, in the colophons of the Bühler manuscripts. Rather, both their syntactic structure and literal content are continually changing in these manuscripts. Were the composite volume of the Bühler manuscripts to be a complete and finalised edition of Rudra's works, both the poet and his scribe would have reproduced a formulaic colophon at the end of every chapter. ${ }^{107}$ In addition, since the creative production of his panegyric works was still underway, the poet was able to experiment with their content by blending and reusing similar versification and rhetorical devices throughout the composite volume. Indeed, it is only when poets are crafting multiple compositions of the same genre simultaneously that they may move from one work to another to determine the ideal content for each. This sort of creative imagining and ideational movement is quite conspicuous in all three Bühler manuscripts. At the start of the composite volume, the poet begins with the $D C$ in which he lauds not just Prince Dāniyāl Mīrzā but also his father, the Emperor Akbar. In folio 4a, he commences his panegyric for Khān Khānān where, apart from composing a few novel verses and passages, he reuses several literary elements from the $D C$. He returns to the composition of the $D C$ in folio I 3 a and he continues to praise Dāniyāl until the end of folio I 8a. For a brief stretch in a couple of folios, he eulogises Prince Khurram (who later became Emperor Shāh Jahān). In the last folio, he presents the last colophon of the anthology, which marks the culmination of the NKC. While still engaged in producing a draft of his works, the poet was able to move from one composition to another to resume work on incomplete sections.

Since Rudra's creative imagination was still at work, none of the eight colophons in three Bühler manuscripts confirms the completion of any one panegyric work in toto. All but the last colophon announce the completion of a specific chapter (ullāsa). The last colophon does mention the title of the NKC, and the poet does come close to acknowledging a prospective ending for the panegyric. But he is still far from confirming its definitive ending. Indeed, among the 28 extant colophons that Rudra composed in his lifetime, this is the first and only instance when he uses the imperative mood (lot lakâra) in a colophon. This mood allows the poet to let his audience know his intentions. If his immediate audience was a scribe, he was merely directing the scribe how he should end his poem. It is even possible that he was communicating with a fellow court-poet. In this case as well, Rudra would be merely expressing his intention, not confirming the end of an ongoing work. Besides, it is evident from his use of the imperative mood that this specific version of his composition was not to be recited before a royal and courtly audience. Nor could the manuscripts be used as a gift for honouring a royal guest. All in all, the final colophon indicates that the composite volume of Bühler manuscripts was a draft edition of his prospective panegyric compositions, and not yet in its final and complete form.

\section{Courtly Chores of a Mercenary Poet}

The historiographical implications that arise from a draft edition of an anthology in a composite volume of manuscripts are significantly different from those arising from a final and

\footnotetext{
${ }^{107}$ In contrast to the Bühler manuscripts, the Baroda manuscript of the $R V M$ that preserves a complete and final edition of Rudra's mahākāvya, contains regularly structured formulaic colophons.
} 
complete edition. A draft edition exposes the creative imagination of a poet and sheds light on the thought processes that underlie and propel literary production. In the case of the Bühler manuscripts attributed to Rudra, his draft shows how he, as a mercenary court-poet, grappled with traditional literary forms and genres while he endeavoured to make sense of his immediate and prospective audiences. In the tenth śloka of the DC (folio $2 \mathrm{a}$ ), the poet describes the context of one his panegyrics.

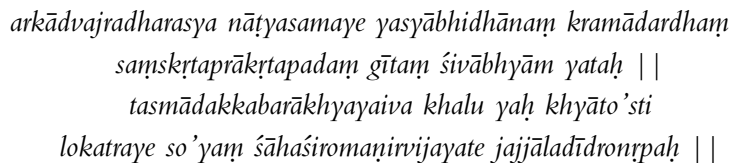

When it is time for a theatrical performance

in the honour of one, who holds lightning and thunderbolt, then an auspicious song, whose diction blends Sanskrit and Prakrit equally, is sung.

Thus, let there be praise for him, who is called Akbar, who is famous in three worlds as Emperor Jajjāladīi ${ }^{108}$ and who is the crest jewel among kings, may he certainly be victorious!

This śloka points to two distinct facets of his panegyric compositions. First, they were to be used for theatrical performances (nātyasamaya) when prominent members of the Mughal elite visited their provincial court. Second, the poet was expected to compose a song whose diction (abhidhāna) would blend both Sanskrit and Prakrit (samskṛtaprākrtapadam gìtam ) verses in equal measure (kramādardham). Here Rudra uses the denomination "prākrta" not just to identify those vernacular languages whose grammatical and literary traditions were deeply influenced by the Sanskrit language, but also to denote the Perso-Arabic literatures that were already prevalent in South Asia.

As early as I596, Rudra had expanded the semantic scope of the term präkrta to include Perso-Arabic languages. In his first literary work, the RVM, he locates both the Delhi Sultanate and the Mughal Empire in "the sphere of the Prakrits" (präkrtamandala). ${ }^{109}$ When two ancestors of the Bāglāna dynasty — Sahaḍa and Yaśavān — were able to conquer the lands of Gurjara, Mālvā and the Delhi Sultanate, the poet identifies them as the victors of "the sphere of the Prakrits". Likewise, following an etymological paradigm prevalent in the Sanskrit grammars of Prakrit languages, Rudra refers to both 'Ala-ud-Dīn Khaljī (r. I296-I3 I6), the emperor of the Delhi Sultanate, and Gajamalladeva, the king of Gujrāt and Mālava, by the epithet "the people of nature" (präkrta-purusa) and he describes their contest for power as "a rage of wild nature" (prakrti-kalaha). ${ }^{110}$ Consequently, when Rudra was expected to compose a poem whose diction borrowed from both Sanskrit and Prakrit languages, it implied that - given his geographical location and his immediate audiences - he had to employ the dialectal registers of Sanskrit, Gurjara, Marhațtha (Maharāsțī Prākrta), Mālvī, Persian and Arabic. This was a novel context for a mercenary Brahmin poet who

\footnotetext{
${ }^{108}$ This is Rudra's Sanskritisation of Jalāl al-Dīn.

${ }^{109}$ RVM 3.50.

${ }^{110}$ This appears in the colophon of the RVM.
} 
was largely schooled in Sanskrit and some literary varieties of Prakrit languages. Moreover, not only did he have a limited understanding of the literary tastes of his Mughal audience, he was incapable of knowing how deeply entrenched his courtly audiences were in the multilingual ecology of "Sanskrit-Prakrit" languages. In a courtly culture, a mercenary poet is not entitled to reject the demands of his patron. At the same time, Rudra had no experience composing multilingual works for elite Muslim audiences.

Before embarking on the project of composing these panegyrics, Rudra had authored just one literary work, the $R V M$, in which he closely observed the conventional norms of Sanskrit kâvya. Indeed, creating this mytho-political narrative of the royal dynasty in power demanded a high degree of grammatical, stylistic and conceptual integrity from the courtpoet. His primary audiences - the Rajput king, his descendants and their followers - were already aware of what they wished to uncover in a celebratory account of their pristine dynasty. Furthermore, he had received elaborate instructions from a fellow court-poet about the narrative he was about to render in verse. In the concluding section of the $R V M$, Rudra reports that he was merely putting into verses a story (kathā) that his learned counterpart, Paṇita Lakṣmaṇa, had narrated to him. ${ }^{111}$ Being an employee of the court, Pandita Lakṣmana had to ensure that Rudra's poem conveyed the officially prescribed version of their dynastic history. Moreover, since Rudra too was a member of the same court, he was already well acquainted with the literary tastes and preferences of his courtly audiences. All these factors contributed to the fuller development of the form and content of the RVM. However, no such reliable additional support was available to Rudra when he was called upon to praise some members of the Mughal elite.

As a mercenary poet, Rudra's duty was to undertake the task entrusted to him by his royal patron. But the court had no way of ensuring that he performed his job in the best possible manner. Although Rudra was a competent Sanskrit poet, his poetic craft and creative imagination have remained unappreciated in the history of Sanskrit literature. One is yet to come across a traditional critique of his literary works. Likewise, a critical appraisal of his poetry is not found in the commentarial literature. As a poet, Rudra does not explicitly recount his interest in developing a novel aesthetic and poetic paradigm in order to move the hearts of his immediate Muslim audiences. In the end, mercenary poets in courtly cultures have to resort to improvisational writing in order to meet the demands of their elite patrons.

The paper used in all three manuscripts of the Bühler collection is of European origin, and some of its folios bear a watermark of Dewdney \& Co. dated I 840 . Thus, it was sometime between I 840 and I 8 September I880, the day Bühler left India for good, that the scribe of these manuscripts was commissioned to copy an older exemplar of Rudra's panegyric works. Unlike the immediate patrons and audiences of Rudra, whoever commissioned the scribe must have been interested in this genre of Sanskrit literature either for monetary gain or for scholarly purposes. With the rise of Indology in Europe and the European historiography in India, a collection of panegeyric works that had failed to interest traditional pandits for almost two centuries suddenly found a new readership who even commissioned fresh copies of older exemplars. Although Bühler was able to procure these manuscripts while they were still fresh, somehow the composite volume was split into three different manuscripts. Given

${ }^{111}$ RVM 20.100. 
the bibliographic practices of the first generation of manuscript collectors and textual scholars in India and Europe, the early history of their rediscovery, identification and transmission remains largely undocumented.

Once the composite volume was divided in three discrete manuscripts, they were viewed by textual scholars and literary critics as "fragmentary" and "corrupt" copies of some yet undiscovered exemplars. Furthermore, most scholars approached the study of these manuscripts as if they were unique copies of the panegyric works of Rudra. They did not pay attention to the anthological nature of these manuscripts. Nor did they notice that the poet was still in the process of figuring out the precise content and form of his prospective compositions. A draft edition of a poetic anthology was read as if it were a muddled copy of multiple panegyrics that-although skillfully composed-were copied with unjustifiable obtuseness by its incompetent scribe. While the poet was lauded for his literary accomplishments, the scribe was blamed for everything that was lacking in the three Bühler manuscripts of the British Library.

Since previous studies neglected the study of the distinctive qualities of the scribe's handwriting, they did not recognise that the same scribe had proficiently copied all three Bühler manuscripts, which originally constituted a composite volume of Rudra's panegyrics. Likewise, they did not pay attention to the form, organisation and content of eight colophons in the Bühler manuscripts. It did not occur to them that these colophons can potentially shed light on the creative imagination of poet, who was still experimenting with genres, languages and rhetorical devices. Since the Bühler collection preserves a draft edition of multiple panegyrics that Rudra was composing simultaneously, several verses and prose passages were being repeated, recast and repurposed. On the one hand, the poet was acutely aware that the literary tastes of the Mughal elite were radically different from those of his Rajput patrons. On the other hand, he had no experience of composing Sanskrit poems for an Islamic and Persianate audience. It is difficult to find decisive evidence in his composition that would reveal how deeply he was inspired to innovate a novel poetic form for his Mughal audiences. Besides, an incomplete draft of a prospective work is not the best means to judge the literary attainments of a poet. Nor is a piece of improvisational writing the ideal mirror for shedding light on the art of mercenary poets in courtly cultures.

Pranav Prakash

Junior Research Fellow, Christ Church, University of Oxford pranav.prakash@chch.ox.ac.uk 